Portland State University

PDXScholar

Spring 6-19-2017

\title{
Mineral Evidence for Generating Compositionally Zoned Rhyolites of the Devine Canyon Tuff, High Lava Plains, Oregon
}

Erik Paul Shafer

Portland State University

Follow this and additional works at: https://pdxscholar.library.pdx.edu/open_access_etds

Part of the Geochemistry Commons, and the Geology Commons Let us know how access to this document benefits you.

Recommended Citation

Shafer, Erik Paul, "Mineral Evidence for Generating Compositionally Zoned Rhyolites of the Devine Canyon Tuff, High Lava Plains, Oregon" (2017). Dissertations and Theses. Paper 4017.

https://doi.org/10.15760/etd.5901

This Thesis is brought to you for free and open access. It has been accepted for inclusion in Dissertations and Theses by an authorized administrator of PDXScholar. Please contact us if we can make this document more accessible: pdxscholar@pdx.edu. 
Mineral Evidence for Generating Compositionally Zoned

Rhyolites of the Devine Canyon Tuff, High Lava Plains,

Oregon

by

Erik Paul Shafer

A thesis submitted in partial fulfillment of the requirements for the degree of

Master of Science

in Geology

Thesis Committee:

Martin J. Streck, Chair

Michael Cummings

Alex Ruzicka

Portland State University

2017 


\begin{abstract}
Large-volume silicic eruptions are often evacuated from magma reservoirs which display gradients in composition, temperature, crystallinity, and volatile content. The 9.7 Ma Devine Canyon Tuff (DCT) of eastern Oregon represents such an eruption, with >300 $\mathrm{km}^{3}$ of compositionally zoned pyroclastic material deposited as a variably-welded ignimbrite. The ignimbrite displays homogenous bulk tuff major element compositions with a wide range of trace element compositions, allowing for the investigation of how these magmas were generated, stored, and modified in the magma reservoir by studying pumices which represent the primary magmas composing the DCT. Five pumices ranging from dacite to rhyolite bulk compositions were selected across the range of trace element compositions and were crushed and sieved to measure how crystallinity and mineral abundances change within each pumice at different particle size fractions. Single alkali feldspar and clinopyroxene crystals were analyzed using EMP and LA ICP-MS from each pumice. Physical results yielded a systematic decrease in crystallinity from $22 \%$ to $3 \%$ going from the dacite to the most evolved rhyolite composition, with the highest crystallinity occurring between $<991-425$ microns for all pumices analyzed. The dacite pumices displayed a glomerocrystic texture not observed in rhyolite pumices. Two populations of crystals were distinguished using single crystal chemical data, one belonging to the rhyolitic magmas and another belonging to the dacitic magma. Acquired mineral data have relevance for how strongly zoned with regard to trace elements the rhyolitic magmas of the DCT were, how these magmas were generated, and how they were stored within the magma reservoir. Applying melt extraction models to explain
\end{abstract}


observed patterns in trace element compositions between pumices is problematic. In this model, the observed range of trace elements in rhyolite pumices would be attributed to two separate melt extraction events from an intermediate crystal mush where the first expulsion of melt from the mush produced the most evolved rhyolite composition and a second expulsion coupled with partial melting produced a second rhyolite with an indistinguishable major element composition but less evolved trace element composition. Mixing of these two rhyolite end members would then be needed for generating the range of intermediate rhyolite compositions. Magma mixing modeled using a mixing equation produced a poor fit for trace elements, suggesting the range of observed trace element compositions cannot be solely generated through the mixing of the extracted rhyolite melts but require processes that subsequently modify the mixed rhyolite compositions. The occurrence of crystal aggregates in the dacite may represent fragments of the crystal mush. However, the dacite was unlikely produced by partial remelting of the crystal mush, generating a less evolved, more intermediate bulk composition. In summary, mush extraction combined with partial melting of the crystal mush and mixing of compositional end members cannot fully explain the trace element patterns observed in the DCT pumices thus warranting further study. 


\section{TABLE OF CONTENTS}

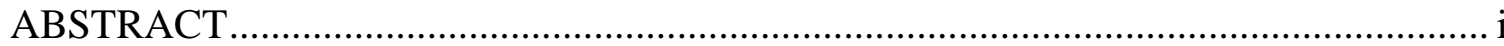

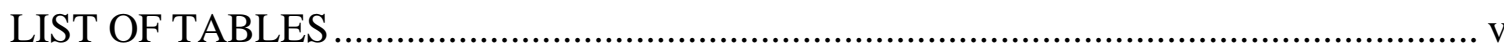

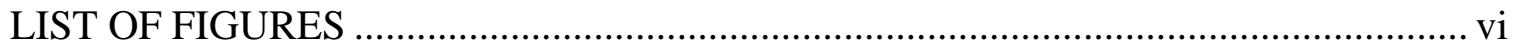

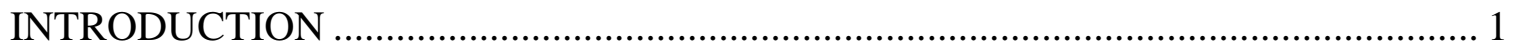

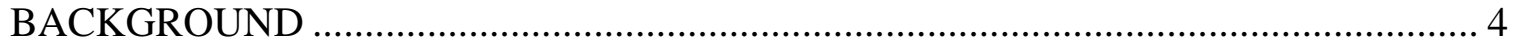

Regional Geology of the High Lava Plains............................................................ 4

High-Silica Rhyolites associated with Tholeiitic Basalts in Bimodal Provinces........... 6

Geologic Background of the Devine Canyon Tuff ................................................... 9

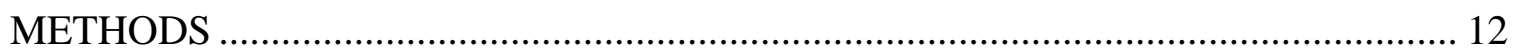

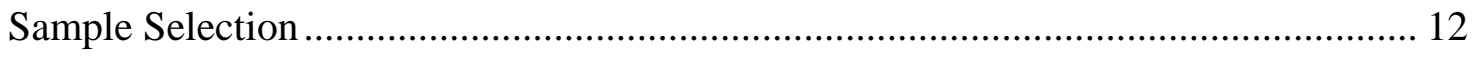

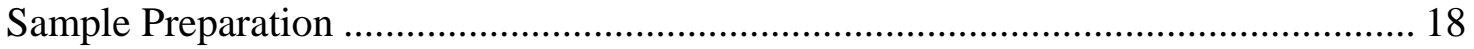

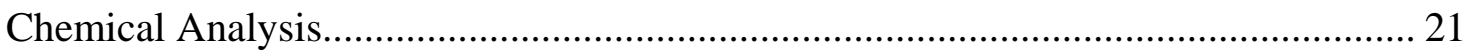

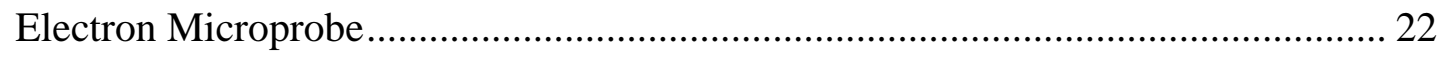

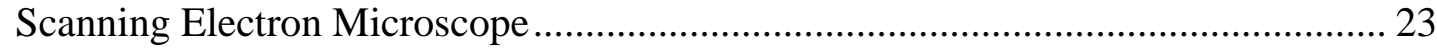

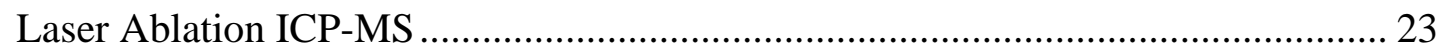

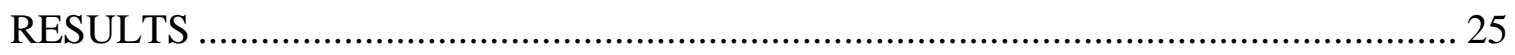

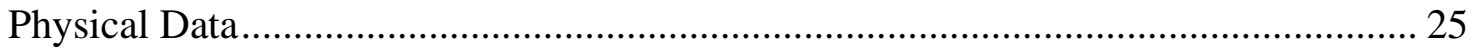

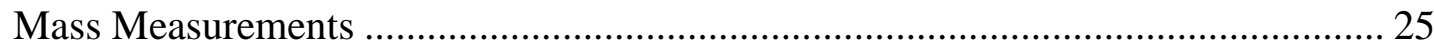

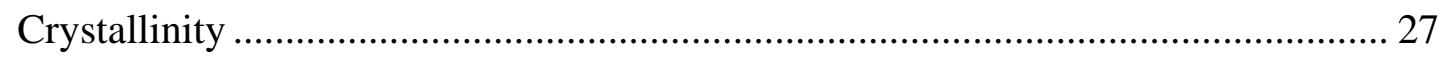

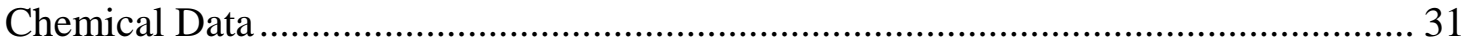

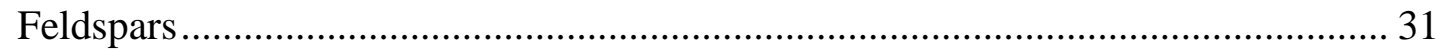

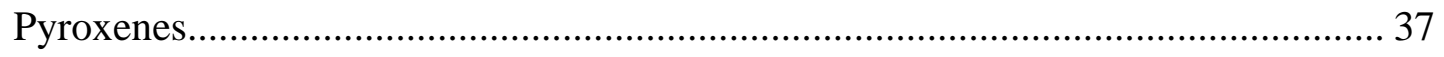

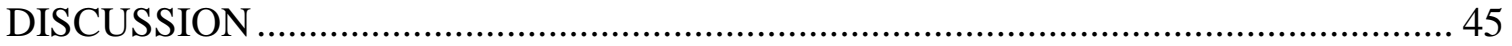

Minerals Record Different Magma Compositions ................................................. 45 
Magma Mixing to Produce Array of Rhyolites.......................................................... 48

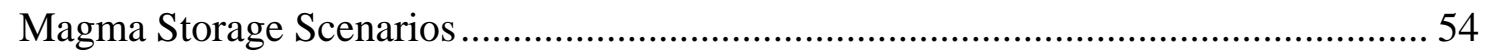

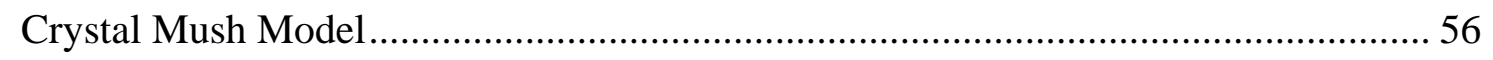

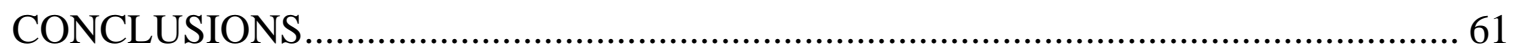

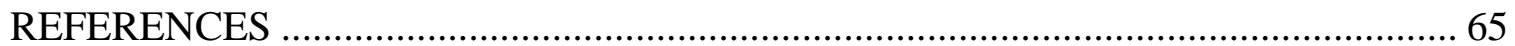




\section{LIST OF TABLES}

Table 1. XRF major element chemistry for each DCT pumice group by Streck (unpublished).

Table 2. XRF trace element chemistry for each DCT pumice group by Streck (unpublished).

Table 3. LA ICP-MS trace element chemistry for each DCT pumice group by Streck (unpublished). 16

Table 4. <125-104 micron size fraction visual estimates of crystallinity...................... 21

Table 5. Crush and sieve measurement of initial pumice samples. ............................. 26

Table 6. DCT crystal and glass masses by group. ….......................................... 26

Table 7. DCT crystallinity and total crystallinity by group.................................... 27

Table 8 . Crystallinity subdivided into felsic and mafic proportions by rhyolite group.... 30

Table 9. Average weight percent EMP major element feldspar chemical composition by

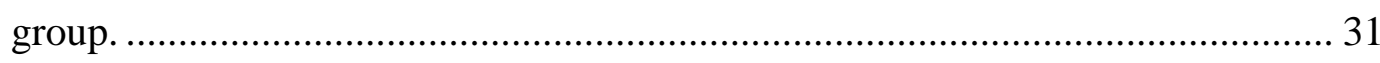

Table 10. Average feldspar end member component composition by group. ................. 32

Table 11. Averaged group LA ICP-MS feldspar trace element data............................. 34

Table 12. Average weight percent EMP clinopyroxene chemical composition by group.38

Table 13. Average clinopyroxene ternary component by group.................................. 38

Table 14. Average LA ICP-MS clinopyroxene trace elements by group...................... 41

Table 15. Average weight percent EMP olivine composition by group........................ 44 


\section{LIST OF FIGURES}

Figure 1 Regional tectonic setting of the High Lava Plains (outlined in red) and surrounding provinces. The black dashed line represents the $0.706{ }^{87} \mathrm{Sr} /{ }^{86} \mathrm{Sr}$ isotope line indicating the edge of the Proterozoic or older craton of North America and younger accreted terrains to the west. The tan shaded regions display extensional normal faulting of the Basin and Range province. Juan de Fuca Plate motion ranges from 16-19 km/Ma. North American Plate motion ranges from 19-

26 km/Ma. Figure by Ford et al. (2013).......................................................... 6

Figure 2. Distribution of the Devine Canyon Tuff. The outcrop distribution as presented by Greene (1973) is indicated by a blue line while the tan shaded region indicates most recent outcrop distribution based upon work by Streck (unpublished) The inferred source caldera is near Burns, Oregon, indicated by a dashed line, but is obscured by intracaldera fill and subsequent volcanism. Figure by Streck (unpublished).

Figure 3. Th vs. $\mathrm{Zr}$ in ppm for the DCT. A positive linear trend is displayed between $\mathrm{Zr}$ and Th from the least evolved sample (lowest $\mathrm{Th}, \mathrm{Zr}$ ) to the most evolved bulk tuff and pumice samples. All groups listed represent pumice samples while bulk tuff samples are displayed separately. Group E is a dacite while groups A through $\mathrm{D}$ are rhyolites. Group A is an air-fall pumice unit. The bulk tuff samples span most of the range of the pumice samples analyzed from each compositional group. Data collected by Streck (unpublished) using LA ICP-MS. 13 
Figure 4. $\mathrm{Nb}$ vs. $\mathrm{Zr}$ in ppm for the DCT. A positive linear trend is displayed between $\mathrm{Zr}$ and $\mathrm{Nb}$ from the least evolved sample (lowest $\mathrm{Nb}, \mathrm{Zr}$ ) to the most evolved bulk tuff and pumice samples. A similar compositional grouping is displayed as shown in Figure 3. Data collected by Streck (unpublished) using LA ICP-MS. 14

Figure 5. C1 chondrite normalized REE diagram for DCT pumice samples by group. A single representative pumice sample was selected from each group for graphing purposes. An overall negative slope and strong Eu anomaly is displayed by all groups, primarily due to the incorporation of Eu into feldspars. Group E displays the smallest Eu anomaly while groups A through D roughly overlap, suggesting crystal fractionation occurred between the generation of the dacite magma, E, and the rhyolite magmas A through D. The depleted LREE relative to HREE can be attributed to the crystallization of chevkinite, a REE mineral with high LREE partition coefficients (Wolff et al., 2015). 17

Figure 6. Primitive mantle normalized spider diagram for DCT pumice samples by group. All groups display an overall negative trend from the most incompatible elements to the least incompatible elements with troughs in $\mathrm{Ba}, \mathrm{Sr}, \mathrm{P}, \mathrm{Eu}$, and $\mathrm{Ti}$, likely due to their incorporation into mineral phases such as alkali feldspar ( $\mathrm{Ba}, \mathrm{Eu})$, apatite (P), and oxides (Ti) 17

Figure 7. Percent crystallinity of each size fraction by group. Group E exhibits an increase in crystallinity with progressively finer size fractions, in contrast to all other groups which typically display a decrease in crystallinity with finer size fractions. 
Figure 8 . Ab vs. Or ternary feldspar end member components by group using EMP data. All groups fall along the same negative slope from the dacite, group E, to groups A through D which cluster tightly together from $40-46 \%$ Or

Figure 9. Ab vs. Or feldspar end member components zoomed in on clustered data from Figure 8. Feldspars sampled from the dacite pumice, group E, still fall within the range of values displayed by the high silica rhyolites of groups A-D. The most potassium rich feldspars ranging from $45-45 \%$ Or occur in groups B through D, which excludes the air fall pumice unit that comprises group A.

Figure 10. Rb vs. Sr in ppm in feldspars using LA ICP-MS data. Sr is typically incorporated into plagioclase crystals while $\mathrm{Rb}$ remains in the melt. Group $\mathrm{E}$ has the widest range of $\mathrm{Sr}$ concentrations that decreases with increasing $\mathrm{Rb}$ and forms a loose cluster with no overlap with the rhyolite groups. Group A is the least enriched in $\mathrm{Rb}$ among rhyolite groups. There is overlap between groups $\mathrm{B}$ through $\mathrm{D}$, however, groups $\mathrm{B}$ and $\mathrm{C}$ form discrete clusters at higher $\mathrm{Rb}$ concentrations. 35

Figure 11. Rb vs. Ba in ppm in feldspars using LA ICP-MS data. Ba serves as a substitute for $\mathrm{K}$ in alkali feldspars. A similar pattern is observed from Figure 10 where $\mathrm{E}$ forms a loose cluster, $\mathrm{A}$ is the least enriched in $\mathrm{Rb}$ when compared to the other rhyolites, and groups $\mathrm{D}$ and $\mathrm{C}$ are the most enriched in $\mathrm{Rb}$ and form clusters of data at higher $\mathrm{Rb}$ values. 36

Figure 12. Rb vs. Ti in ppm in feldspars using LA ICP-MS data. Group E forms a discrete cluster at high Ti concentrations with a greater separation observed than 
with $\mathrm{Sr}$ or $\mathrm{Ba}$. Group A is displays the second lowest $\mathrm{Rb}$ concentrations and second highest Ti concentrations. There is an overlap between groups A through D while groups $\mathrm{B}$ and $\mathrm{C}$ once again display two clusters of data at $\sim 50$ and $\sim 60$ ppm Rb. 36

Figure 13. Ba vs. Eu in ppm in feldspars using LA ICP-MS data in a log-log plot. Once more, group E forms a distinct cluster at higher Ba and Eu concentrations. Group $\mathrm{A}$ is the most enriched in $\mathrm{Ba}$ and Eu amongst the rhyolite groups. A subset of crystals from groups A and B form a more enriched concentration cluster separate from the remaining rhyolite groups which form a third, least enriched cluster.... 37

Figure 14. Fs vs. Wo pyroxene end member components by group. The clinopyroxenes cluster together, with group B and group C having outlying orthopyroxene crystals which were not commonly observed within the samples analyzed and represent a small subset of crystals present. 39

Figure 15. Fs vs. Wo pyroxene end member components by group zoomed in on clustered data from Figure 14. Two features are noted when the clustered data is enlarged, first, the rhyolite groups display no apparent trend but appear as a cloud with large overlaps between rhyolite groups A through D, secondly, the dacite sample does display a clear negative slope with increasing FeO that has some overlap with the rhyolite groups but largely lay outside of the cloud of rhyolite pyroxene samples.

Figure 16. Y vs. Zr in ppm in clinopyroxenes using LA ICP-MS data. Group E forms a cluster with the lowest Y and Zr concentrations. Group B spans the entire 
concentration range of analyzed crystals, having the lowest and highest $\mathrm{Y}, \mathrm{Zr}$, concentrations. Groups B through D all overlap with a group A forming a loose cluster of data 42

Figure 17. Er vs. $\mathrm{Yb}$ in ppm in clinopyroxenes using LA ICP-MS trace data. Group E forms a distinct grouping of data, representing the least enriched compositions in Er and $\mathrm{Yb}$. A second grouping of data consisting of groups B through D forms an intermediate composition while a third grouping of data consisting of groups A through D representing the most enriched compositions. A single crystal from group B represents the most enriched composition in Er and $\mathrm{Yb}$. Note that crystals from group A represent the most enriched composition amongst all groups when comparing Er and $\mathrm{Yb}$.

Figure 18. Ce vs. La in ppm in clinopyroxenes using LA ICP-MS trace element data. Group E forms the less enriched end of the overall positive linear trend, but does not exhibit the same degree of separation from the rhyolite groups when compared to Figure 17. In contrast with Figure 17, Group A represents the second least enriched composition, however, groups A through D all display a large amount of overlap with each other.

Figure 19. Spider diagram of average group pyroxene incompatible elements normalized to primitive mantle composition from Sun and McDonough (1989). All groups display troughs in $\mathrm{Rb}, \mathrm{Ba}, \mathrm{Pb}, \mathrm{Sr}$, and $\mathrm{Ti}$. With the exception of $\mathrm{Sr}$, group $\mathrm{A}$ represents the most enriched concentrations from $\mathrm{La}$ to $\mathrm{Yb}$, however, from $\mathrm{Rb}$ to Ta, group B represents the most enriched concentrations in HREEs, displaying a 
pattern that deviates from the otherwise consistent shape of the spider diagram. Group E is consistently the least enriched composition, particularly with regards to the HREEs, with the exception of Sr.

Figure 20. Mixing proportions, $\mathrm{X}$, for group B rhyolite. The average mixing proportion, $\mathrm{X}$, is displayed as a horizontal black line. The magma mixing model provides a rough fit for LREEs and some HREEs, however, a linear relationship is not observed. The relative standard deviation for the model for group B is $13.3 \%$... 51

Figure 21. Mixing proportions, $\mathrm{X}$, for group $\mathrm{C}$ rhyolite. The average mixing proportion, $\mathrm{X}$, is displayed as a horizontal black line. Similar to Figure 20, the magma mixing model provides a rough fit, however, a linear relationship is not observed. The relative standard deviation for the model for group B is $37.7 \%$, signifying the fit for the magma mixing model is less accurate for group $\mathrm{C}$ being the mixing product of groups $\mathrm{A}$ and $\mathrm{D}$. 52

Figure 22. Schematic of cumulate remelting to produce compositionally zoned crystalpoor rhyolitic magma from an intermediate crystal mush. Remelting of the underlying crystal mush could produce the dacitic composition observed in the DCT, supported by the glomerocrystic texture of minerals in group E. Figure modified from Wolf et al. (2015) 59 


\section{INTRODUCTION}

Large-volume $\left(>100 \mathrm{~km}^{3}\right)$ silicic eruptions are typically evacuated from magma chambers which display gradients in chemical composition, temperature, crystallinity, and mineralogy (Hildreth, 1981; Streck and Grunder, 1997; Cathey and Nash, 2004). Zoned, large-volume silicic magma chambers are of particular interest because: (1) the high viscosity of silicic magmas should inhibit efficient crystal-melt separation, yet many silicic ash-flow tuffs are crystal-poor; (2) high trace element variation relative to low major element variation; (3) in addition to compositional gradients, compositional gaps also occur which are reflected in chemistry of the glass shards, crystals, bulk pumice, and bulk tuff samples, suggesting discrete volumes of silicic magma were present within the magma chamber without much interaction; (4) compositional gradients and gaps have implications for magma reservoir geometry, magma storage, and magmatic differentiation processes to allow discrete volumes of silicic magma to evolve in nearequilibrium conditions, sometimes with distinct chemical compositions and mineral assemblages; (5) caldera formation caused by roof collapse after either a critical volume of magma has been erupted or the roof could no longer span a growing magma chamber suggests that a majority of the magma has been evacuated, allowing chamber-wide zonation and differentiation processes to be evaluated in the pyroclastic products deposited from such eruptive events (Hildreth, 1981; Streck and Grunder, 1997; Cathey and Nash, 2004; Christiansen, 2005; Ellis et al., 2010). By examining the chemical composition and mineralogy of pyroclastic deposits produced from caldera-forming eruptions, the magma generation, storage, and differentiation processes of silicic magmas 
can be investigated. The Devine Canyon Tuff (DCT), located in the High Lava Plains (HLP) of eastern Oregon, is mostly composed of high-silica (>75 wt. \% $\mathrm{SiO}_{2}$ ) rhyolite which displays significant variation in trace element concentration across a narrow $\mathrm{SiO}_{2}$ range of $\sim 2$ wt. $\%$. With an eruptive volume of $>300 \mathrm{~km}^{3}$ covering $20,000 \mathrm{~km}^{2}$, the DCT is the second best exposed ash-flow tuff in Oregon after the Rattlesnake Tuff (Greene, 1973; Ford et al., 2013). The DCT allows for the petrologic examination of a largevolume silicic eruption where magmatic processes leading to the development of chemical gradients can be investigated. To investigate such processes, pumice samples collected from the DCT were divided into five groups based on trace element concentration derived from the overall trace element concentration range displayed by previously analyzed bulk tuff samples collected by Streck (unpublished) (Figure 3 and Figure 4), with a single pumice selected as a representative sample for each group for further investigation, with the exception of groups C and D which had a second sample prepared and analyzed to test the validity of assumption that the pumices within each group are similar. The incompatible elements and rare earth elements for each group were used to generate REE and spider diagram plots (Figure 5 and Figure 6).

This study reports the physical and chemical characteristics of analyzed DCT pumices, including crystallinity, mineral proportionality, as well as crystal chemistry to examine trace element variation in feldspars and pyroxenes to gain insight into how many distinct magma compositions may be present within the DCT and how these magmas may be related to one another and stored within the magma reservoir. To accomplish this, 
existing DCT bulk tuff chemical data (Streck, unpublished) were used to supplement the data generated by this study. 


\section{BACKGROUND}

\section{Regional Geology of the High Lava Plains}

The Pacific Northwest is a complex tectonic-magmatic region involving the Yellowstone hotspot, the subduction of the Juan de Fuca plate, and the extension of the Basin and Range province (Jordan et al., 2004; Ford et al., 2013). The geology of the High Lava Plains (HLP) of eastern Oregon as described by Jordan et al. (2004) and Ford et al. (2013) records multiple episodes of Oligocene and younger volcanism. The HLP comprises a late Miocene and younger volcanic province that is approximately $275 \mathrm{~km}$ long and $90 \mathrm{~km}$ wide, extending across central and eastern Oregon. The HLP are bounded by the Cascade volcanic arc, the northwestern Basin and Range province, the Owyhee Plateau, and the Blue Mountains. The low relief topography of the HLP is characterized by late Miocene and younger high-alumina olivine tholeiitic (HAOT) basalt lava flows, ash-flow tuffs, rhyolite domes, and volcaniclastic and tuffaceous sediments with sparsely exposed Oligocene through Miocene volcanic rocks. The Brothers Fault Zone which cuts through the HLP is characterized by northwest-trending normal faults with offsets generally $<10 \mathrm{~m}$. Large normal faults of the Basin and Range province decrease in topographic and structural offset northward into the HLP. The HLP also contains rocks from Cenozoic volcanism which predate the bimodal (basalt-rhyolite) volcanism of the HLP, including the Clarno Formation (54-40 Ma, >1800 m thickness) which likely underlies the HLP, the John Day Formation (38.5-20 Ma, >1000 m thickness), and Steens

Basalt (17.5-15 Ma, $60000 \mathrm{~km}^{3}$ ) lava flows (Jordan et al., 2004; Ford et al., 2013). 
The HLP are characterized by bimodal basalt-rhyolite volcanism since the late Miocene, consisting of low-potassium HAOT basalts, rhyolite domes ( $>60$ domes), lava flows, and ash-flow tuffs. Silicic volcanism over the past 12 Ma has produced a W-NW younging trend that mirrors the coeval E-NE age-progressive rhyolites of the Snake River Plain (SRP) formed by the Yellowstone hotspot. The HLP contain three large volume (>100 km³) ash-flow tuffs: the Rattlesnake Tuff, Devine Canyon Tuff, and Prater Creek Tuff, of which only the Rattlesnake Tuff has been studied in detail (Streck, 1995; Streck and Grunder, 1997; Streck and Grunder, 1999; Ford et al., 2013). The most recent (<1 Ma) rhyolitic volcanism has occurred near Newberry Volcano. Basaltic volcanism occurring coevally does not display the same spatial-temporal pattern as rhyolitic volcanism in either the HLP or the SRP provinces. The most primitive HAOT basalts resemble mid-ocean ridge basalts. The age-progressive trend of silicic volcanism in the HLP has been attributed to multiple sources, including mantle upwelling in response to slab rollback and steepening, crustal extension, extension coupled with crustal block rotation, westward spread of a portion of the Yellowstone plume head, changes in the geometry of subduction, or entrainment of plume head material in subduction-induced asthenospheric counter flow (Jordan et al., 2004; Ford et al., 2013). 


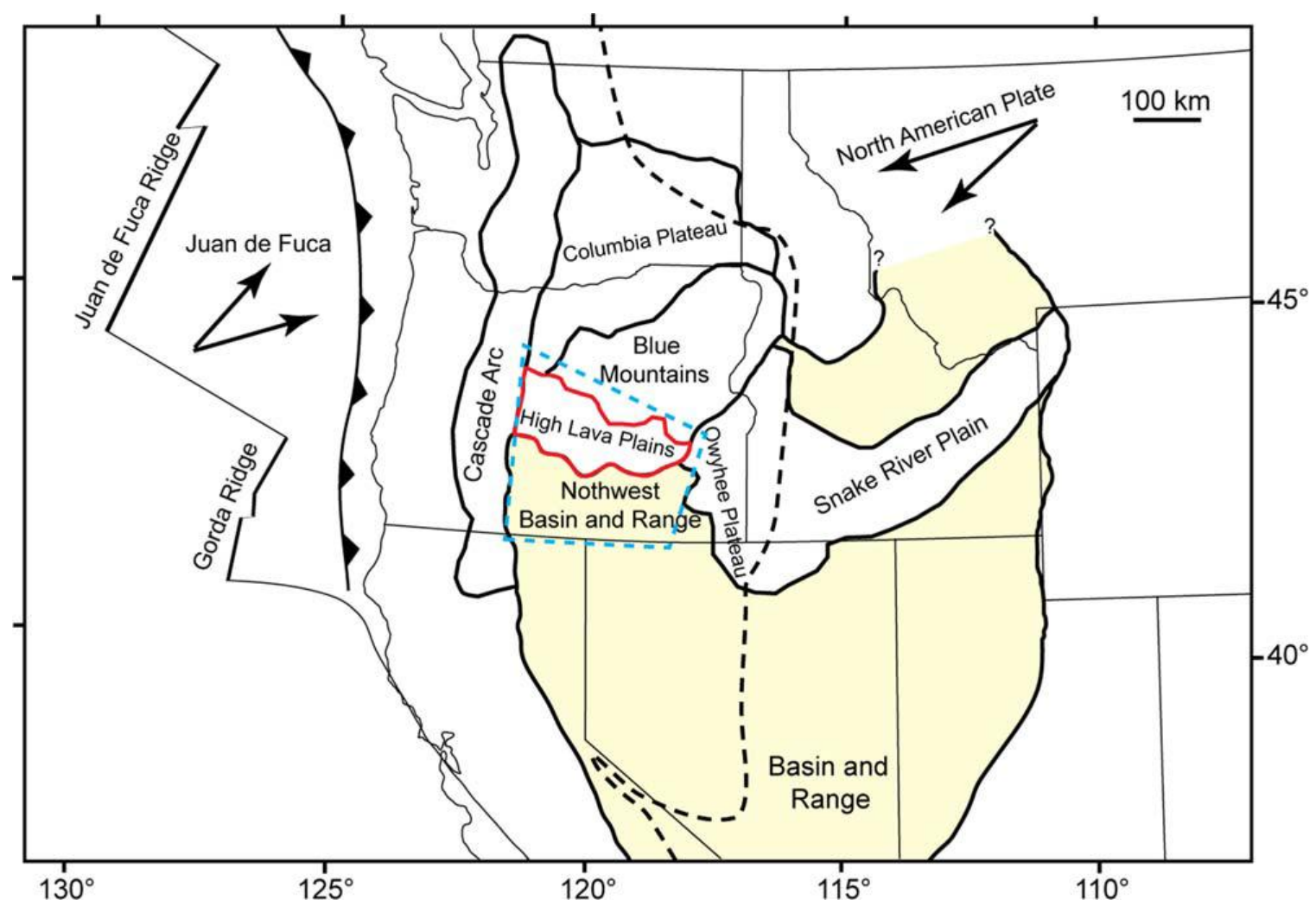

Figure 1 Regional tectonic setting of the High Lava Plains (outlined in red) and surrounding provinces. The black dashed line represents the $0.706{ }^{87} \mathrm{Sr} /{ }^{86} \mathrm{Sr}$ isotope line indicating the edge of the Proterozoic or older craton of North America and younger accreted terrains to the west. The tan shaded regions display extensional normal faulting of the Basin and Range province. Juan de Fuca Plate motion ranges from 16-19 km/Ma. North American Plate motion ranges from 19-26 km/Ma. Figure by Ford et al. (2013).

\section{High-Silica Rhyolites associated with Tholeiitic Basalts in Bimodal Provinces}

Large-volume silicic ash-flow tuffs are typically divided into two categories: hot, dry, crystal-poor rhyolites or cool, wet, crystal-rich dacites, often termed "monotonous intermediates," as labeled by Hildreth (1981), due to the lack of chemical zonation in voluminous dacitic ash-flow tuffs. Hot-dry-crystal-poor rhyolites are described by Christiansen (2005) as having eruptive temperatures $>800{ }^{\circ} \mathrm{C}$, low $\mathrm{H}_{2} \mathrm{O}$ fugacities, and $<20 \%$ crystallinity (Streck and Grunder, 2008; Streck, 2014). Hot-dry-crystal-poor rhyolites are often associated with tholeiitic magmas in bimodal provinces of extensional settings and hotspots (Streck and Grunder, 2008; Streck, 2014). The "monotonous 
intermediates" (cool-wet-crystal-rich dacites) have eruptive temperatures $<800{ }^{\circ} \mathrm{C}$, high $\mathrm{H}_{2} \mathrm{O}$ fugacities, and 40-50\% crystallinity (Streck and Grunder, 2008; Streck, 2014). Coolwet-crystal-rich dacites are often associated with calc-alkaline magmas in subduction zones where large volumes of wet, mantle-derived magma can fuel shallow magma systems (Streck and Grunder, 2008; Streck, 2014). Tectonic setting (hotspot and extensional setting vs. subduction zone) controls the magmatic temperature, which along with crystallinity, $\mathrm{H}_{2} \mathrm{O}$ fugacity, and magma composition control the viscosity of the melt. Hot, crystal-poor rhyolites are characterized by low viscosities, anhydrous mineral species, elevated Fe-concentrations, with mafic minerals such as Fe-rich olivine (fayalite) and pyroxene (hedenbergite), and display an enrichment of incompatible trace elements (Streck and Grunder, 2008; Streck, 2014). The magmatic evolution of hot, crystal-poor rhyolites is thought to be dominated by crystal fractionation processes resulting in vertical chemical zonation due to crystal-melt separation as a result of low viscosities from high magmatic temperatures, low crystallinity, and low $\mathrm{H}_{2} \mathrm{O}$ fugacities (Streck and Grunder, 2008; Streck, 2014). Compositionally zoned silicic magmas are thought to be accumulated in a magma reservoir such that when progressively tapped downward during an eruption produces an inverted record of the original zoned magma column with deposition of the most evolved magma first followed by less evolved magmatic compositions (Christiansen, 2005; Streck and Grunder, 2008; Streck, 2014). The mineral assemblages of crystal-poor, high-silica rhyolites are typically at equilibrium making them useful for investigating the pre-eruptive magmatic state rather than the origin of the high-silica magma itself and may denote discrete magmatic compositions (Streck and 
Grunder, 2008; Streck, 2014). The degree of magmatic evolution by prior crystal fractionation may obscure the petrogenesis of high-silica rhyolites, thus the least-evolved rhyolites are essential to understanding the magmatic history. Cool, crystal-rich dacites lack evidence for crystal fractionation or chemical zonation with moderately heterogeneous magmas due to inhibited crystal-melt separation and convection in slabshaped, crystal-rich, high viscosity magma chambers that were likely never near liquidus conditions. Hot, crystal-poor rhyolites may be up to two orders of magnitude less viscous than cool, crystal-rich dacites, primarily due to the difference in crystallinity, in addition to temperature and volatile contents (Christiansen, 2005).

One popular model used to describe the petrogenesis of high-silica rhyolites is the crystal mush model where high-silica melt is extracted from a granodioritic magma at $\sim 50 \%$ or higher crystallinity where convection can no longer occur and the expulsion of interstitial high-silica melt occurs by compaction of crystal matrix due to settling (Bachmann and Bergantz, 2004; Hildreth, 2004; Christiansen, 2005). Crystal mush models are often invoked for the generation of high-silica magmas but do not adequately account for the observed eruptive temperatures, chemical compositions, and mineral assemblages in rhyolitic ash-flow tuff deposits from bimodal provinces such as the HLP and SNP (Christiansen, 2005; Streck and Grunder, 2008; Streck, 2014). Large volumes $>2000 \mathrm{~km}^{3}$ of crystal mush would be required to produce $>100 \mathrm{~km}^{3}$ of crystal-poor rhyolite which is not present except in the deposits of voluminous crystal-rich dacites (Streck and Grunder, 2008). Initial parent high-silica magmas can be generated through partial melting (5-20\%) of mafic crust or fractional crystallization from a less-evolved 
basaltic magma (Christiansen, 2005; Streck and Grunder, 2008; Streck, 2014). Pure mixing between two end-members (within a single magma body or multiple interconnected chambers) may or may not explain the range of discrete rhyolite magmas exhibited by different equilibrium mineralogies and magma compositions that erupted contemporaneously (Streck and Grunder, 2008; Streck, 2014).

\section{Geologic Background of the Devine Canyon Tuff}

The 9.7 Ma Devine Canyon Tuff, first described by Greene (1973) and further investigated by Wacaster et al. (2011), has an extent of $20,000 \mathrm{~km}^{2}$ with an eruptive volume $>300 \mathrm{~km}^{3}$, representing one of the most widespread (Figure 2) and voluminous tuffs in eastern Oregon. The majority of the DCT outcrops are located within the Harney Basin which likely originated from a caldera due to the volume of material erupted which is now obscured due to intracaldera fill and subsequent volcanism The DCT flowed radially from its proposed source near the town of Burns, Oregon where the ash-flow tuff sheet is thickest and decreases in thickness distally. The DCT is mostly rhyolitic in composition, ranging from 74.6-77.6 wt. \% $\mathrm{SiO}_{2}$, displaying a limited range in major element concentrations but a wide variation in trace element concentrations, suggesting magmatic differentiation occurred. Dacitic compositions are found as rare dacite pumices and as streaks in banded dacite-rhyolite pumices. The DCT contains vitric, devitrified, and vapor phase zones with varying densities and degrees of welding, from unwelded to densely welded, composing a single ash-flow tuff with an uninterrupted cooling history, suggesting the magma chamber was emptied during a single eruptive episode (Smith, 1960; Ross and Smith, 1961; Greene, 1973; Wacaster et al., 2011). The DCT varies from 
crystal-poor to crystal-rich, with a total phenocryst content range of $5 \%$ to $30 \%$. The DCT contains euhedral to subhedral phenocrysts of alkali feldspar (sanidine) and quartz as the major mineral phases with minor clinopyroxene (hedenbergite) and olivine (fayalite) (Greene, 1973; Wacaster et al., 2011; Streck, 2014, this report). The groundmass consists of variably welded volcanic glass shards, pumice, and sparse lithic fragments. Reported accessory mineral phases include apatite, britholite, aenigmatite, chevkinite, Fe-Ti oxides, and zircon. Glass shards composing the groundmass vary from undistorted fragments of vesicle walls (cuspate forms) to stretched and flattened (eutaxtic texture), proportional to the degree of welding. Pumice occurs in a variety of forms, from highly porous in unwelded sections to fiamme (vitric lenticular discs) in densely-welded sections. Pumice content varies throughout the tuff while generally decreasing towards the margins of the ash-flow tuff sheet, suggesting it was winnowed out as the ash-flow tuff advanced. The DCT is also zoned with regard to phenocryst content, with a phenocryst-poor base transitioning to a phenocryst-rich top, as well as being more crystal-rich near the proposed source where the tuff is thickest and decreasing in crystallinity distally towards the margins of the tuff sheet (Greene, 1973; Wacaster et al., 2011). 


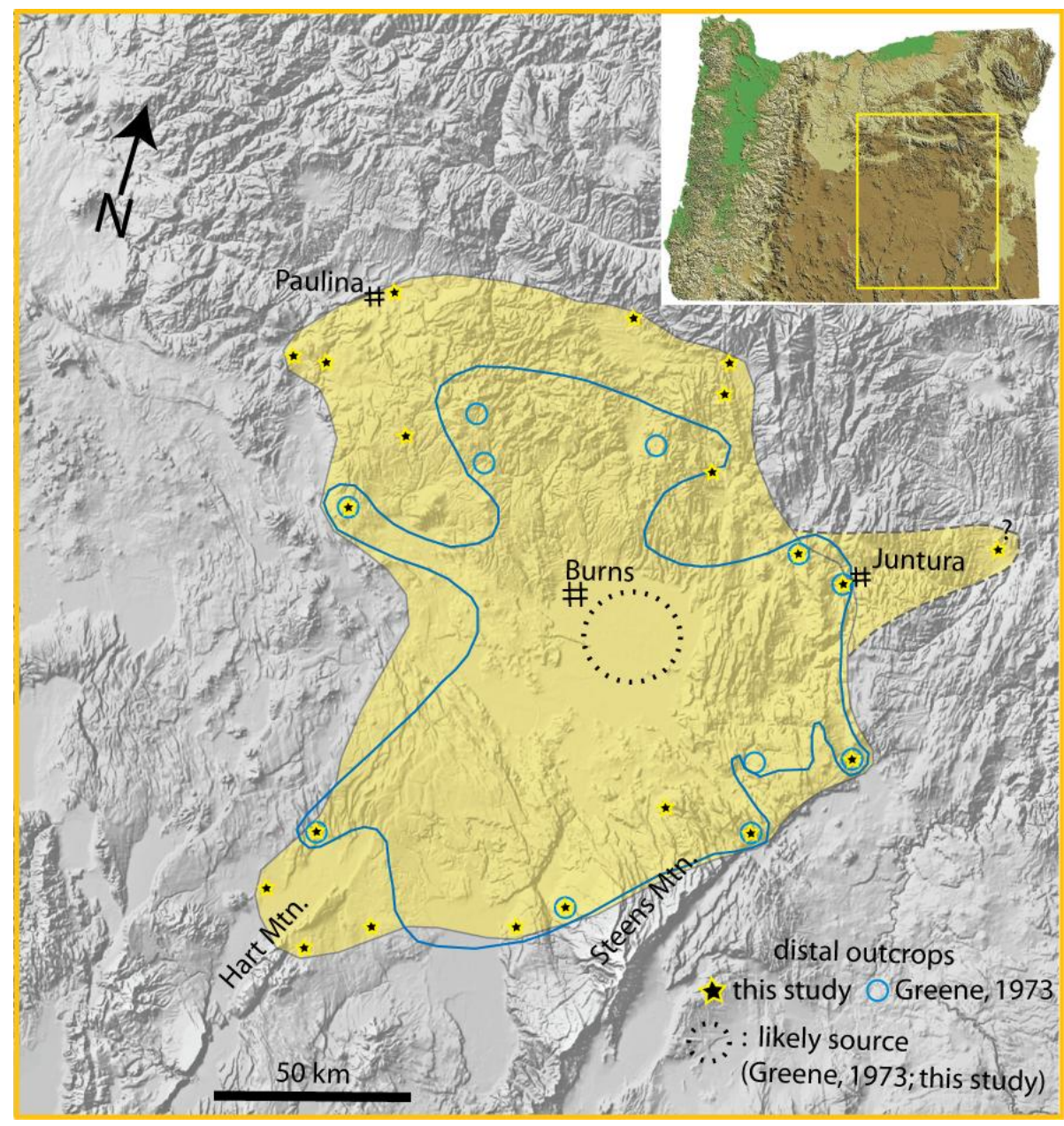

Figure 2. Distribution of the Devine Canyon Tuff. The outcrop distribution as presented by Greene (1973) is indicated by a blue line while the tan shaded region indicates most recent outcrop distribution based upon work by Streck (unpublished) The inferred source caldera is near Burns, Oregon, indicated by a dashed line, but is obscured by intracaldera fill and subsequent volcanism. Figure by Streck (unpublished). 


\section{METHODS}

\section{Sample Selection}

All DCT bulk pumice and bulk tuff samples were collected by Martin Streck and Susan Wacaster in the Harney Basin of eastern Oregon. Previously collected XRF and LA ICP-MS bulk tuff and bulk pumice data by Streck (unpublished) were initially used to examine DCT chemical data for trends or clustering of data based upon trace element concentrations from individual pumice and bulk tuff samples. XRF and ICP-MS chemical analyses of collected pumice and bulk tuff samples from the DCT displayed a wide trace element concentration range over a narrow major element range. Clustering of data, particularly $\mathrm{Zr}, \mathrm{Nb}$, and $\mathrm{Th}$ variations, provided the basis for designating five pumice groups, A through E (Figure 3 and Figure 4; Table 1, Table 2, and Table 3). Groups A through $\mathrm{D}$ are rhyolitic in composition with 74.80-77.05\% $\mathrm{SiO}_{2}$ while group $\mathrm{E}$, consisting of a single pumice, is dacitic in composition with $68.95 \% \mathrm{SiO}_{2}$. Group A being the most silicic and enriched in incompatible trace elements and group E being the least silicic and enriched in incompatible trace elements. The number of pumices within each group varied from 1-4 samples. For the purposes of this study, single pumice samples from B to E and multiple small pumices to yield a pumice composite from A were selected to represent the whole suite of observed trace element concentrations within the DCT. Group A rhyolite is found as precursor pumice fallout deposit, requiring that multiple pumices be crushed together to achieve the desired sample weight, while the other pumices were from the ash-flow tuff. The selected representative pumices were prepared for physical and chemical analysis of observed minerals. To test whether the 
selected pumices were representative and approximately homogeneous within each group rather than being heterogeneous with different proportionalities or assemblages of minerals, a duplicate was prepared for group $\mathrm{C}$ and compared to the results of the initial group $\mathrm{C}$ pumice preparation. In addition, a second separate sample was prepared from the group D pumices to test the assumption that these pumices are within-group relatively homogenous by comparing the duplicate with the other pumice sample evaluated from the same group.

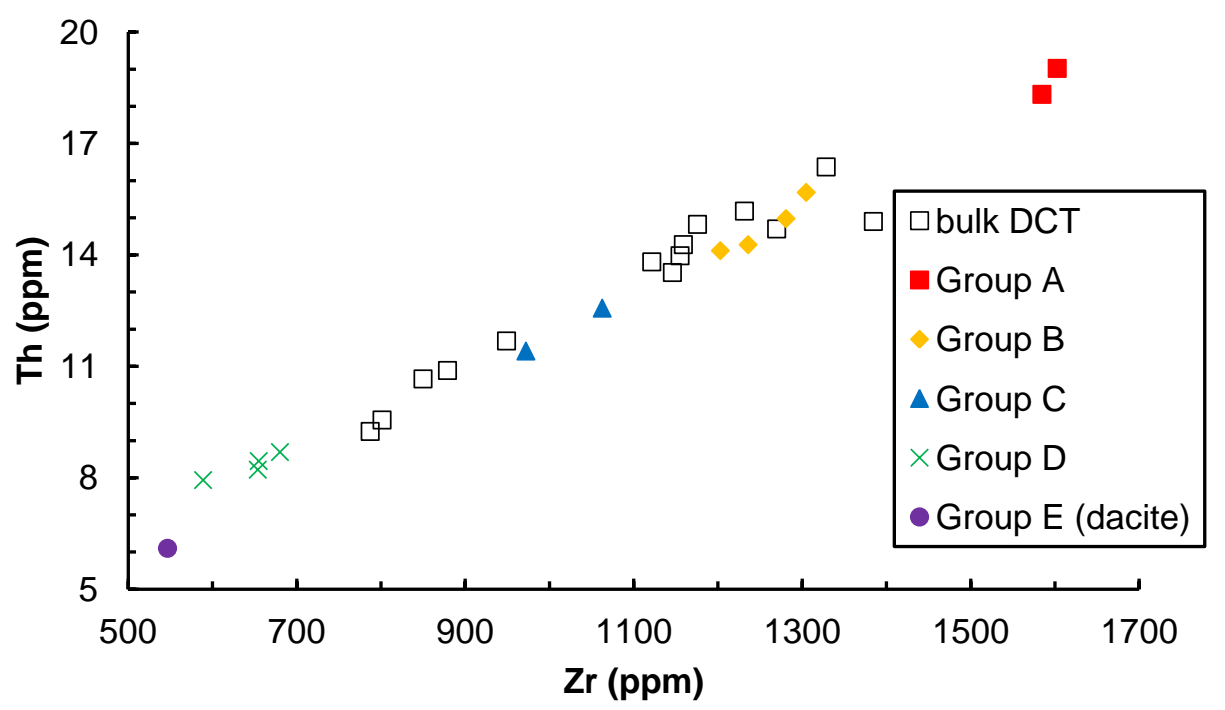

Figure 3. Th vs. Zr in ppm for the DCT. A positive linear trend is displayed between $\mathrm{Zr}$ and Th from the least evolved sample (lowest $\mathrm{Th}, \mathrm{Zr}$ ) to the most evolved bulk tuff and pumice samples. All groups listed represent pumice samples while bulk tuff samples are displayed separately. Group $\mathrm{E}$ is a dacite while groups $A$ through $D$ are rhyolites. Group $A$ is an air-fall pumice unit. The bulk tuff samples span most of the range of the pumice samples analyzed from each compositional group. Data collected by Streck (unpublished) using LA ICP-MS. 


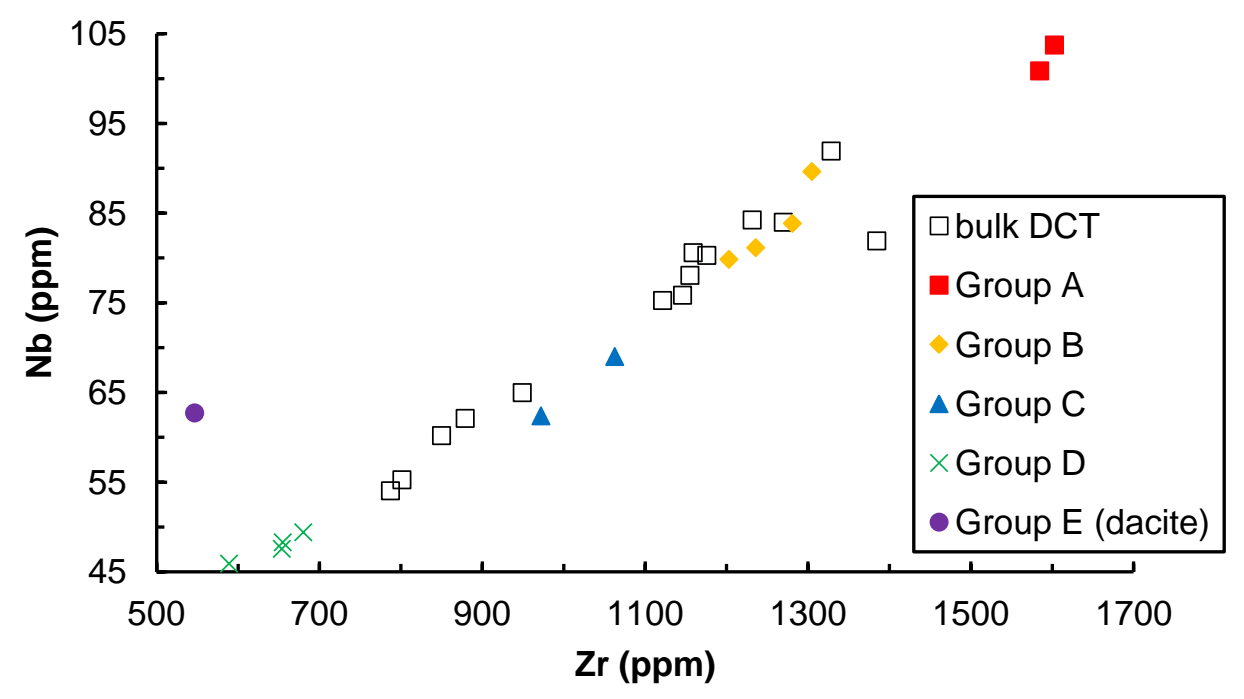

Figure 4. $\mathrm{Nb}$ vs. $\mathrm{Zr}$ in ppm for the DCT. A positive linear trend is displayed between $\mathrm{Zr}$ and $\mathrm{Nb}$ from the least evolved sample (lowest $\mathrm{Nb}, \mathrm{Zr}$ ) to the most evolved bulk tuff and pumice samples. A similar compositional grouping is displayed as shown in Figure 3. Data collected by Streck (unpublished) using LA ICP-MS. 
Table 1. XRF major element chemistry for each DCT pumice group by Streck (unpublished).

\begin{tabular}{|c|c|c|c|c|c|c|}
\hline \multirow{2}{*}{$\begin{array}{l}\text { Group } \\
\text { Sample ID }\end{array}$} & \multirow{2}{*}{$\frac{\text { Group A }}{\text { DC11-1P }}$} & \multirow{2}{*}{$\frac{\text { Group B }}{\text { DC1133P8 }}$} & \multirow{2}{*}{$\frac{\text { Group C }}{10-28 D C-A}$} & \multicolumn{2}{|c|}{ Group D } & \multirow{2}{*}{$\frac{\text { Group E }}{\mathrm{DC} 1133 \mathrm{P} 11}$} \\
\hline & & & & DC1133P7 & DC1133P13 & \\
\hline \multicolumn{7}{|c|}{ XRF (wt. \%) } \\
\hline $\mathrm{SiO}_{2}$ & 76.36 & 76.69 & 76.94 & 76.67 & 75.18 & 68.95 \\
\hline $\mathrm{TiO}_{2}$ & 0.175 & 0.173 & 0.200 & 0.223 & 0.235 & 0.470 \\
\hline $\mathrm{Al}_{2} \mathrm{O}_{3}$ & 10.87 & 10.60 & 10.96 & 10.81 & 11.68 & 13.47 \\
\hline $\mathrm{FeO}^{*}$ & 3.28 & 2.89 & 2.69 & 2.64 & 2.77 & 5.17 \\
\hline $\mathrm{MnO}$ & 0.060 & 0.059 & 0.054 & 0.067 & 0.077 & 0.188 \\
\hline $\mathrm{MgO}$ & 0.11 & 0.00 & 0.08 & 0.10 & 0.06 & 0.04 \\
\hline $\mathrm{CaO}$ & 0.20 & 0.20 & 0.23 & 0.43 & 0.52 & 1.24 \\
\hline $\mathrm{Na}_{2} \mathrm{O}$ & 3.50 & 3.03 & 2.47 & 2.84 & 3.25 & 4.01 \\
\hline $\mathrm{K}_{2} \mathrm{O}$ & 5.43 & 6.35 & 6.37 & 6.12 & 6.16 & 6.42 \\
\hline $\mathrm{P}_{2} \mathrm{O}_{5}$ & 0.008 & 0.024 & 0.013 & 0.102 & 0.081 & 0.054 \\
\hline
\end{tabular}

Note: $\mathrm{FeO}^{*}$ is the total amount of all $\mathrm{FeO}$ present in all oxidation states.

Table 2. XRF trace element chemistry for each DCT pumice group by Streck (unpublished).

\begin{tabular}{lcccccc}
\hline \hline Group & Group A & Group B & Group C & \multicolumn{2}{c}{ Group D } & Group E \\
Sample ID & DC11-1P & DC1133P8 & 10-28DC-A & DC1133P7 & DC1133P13 & DC1133P11 \\
\hline XRF (ppm) & & & & & & \\
$\mathrm{Ni}$ & 5 & 10 & 5 & 21 & 16 & 13 \\
$\mathrm{Cr}$ & 4 & 3 & 4 & 5 & 3 & 4 \\
$\mathrm{Sc}$ & 0 & 0 & 1 & 1 & 1 & 0 \\
$\mathrm{~V}$ & 6 & 2 & 4 & 4 & 2 & 4 \\
$\mathrm{Ba}$ & 8 & 13 & 76 & 75 & 143 & 75 \\
$\mathrm{Rb}$ & 177 & 139 & 130 & 84 & 74 & 59 \\
$\mathrm{Sr}$ & 5 & 1 & 4 & 8 & 11 & 8 \\
$\mathrm{Zr}$ & 1449 & 1171 & 993 & 658 & 573 & 539 \\
$\mathrm{Y}$ & 191 & 152 & 130 & 89 & 82 & 102 \\
$\mathrm{Nb}$ & 107.2 & 81.1 & 69.9 & 49.1 & 45.5 & 62.2 \\
$\mathrm{Ga}$ & 29 & 29 & 28 & 25 & 27 & 30 \\
$\mathrm{Cu}$ & 6 & 10 & 3 & 20 & 12 & 14 \\
$\mathrm{Zn}$ & 313 & 240 & 205 & 149 & 137 & 188 \\
$\mathrm{~Pb}$ & 44 & 32 & 21 & 18 & 16 & 16 \\
$\mathrm{La}$ & 77 & 85 & 93 & 114 & 117 & 125 \\
$\mathrm{Ce}$ & 174 & 175 & 188 & 227 & 224 & 251 \\
$\mathrm{Th}$ & 19 & 14 & 12 & 8 & 9 & 7 \\
$\mathrm{Nd}$ & 93 & 90 & 92 & 100 & 96 & 120 \\
$\mathrm{U}$ & 8 & 5 & 4 & 4 & 3 & 2 \\
\hline
\end{tabular}


Table 3. LA ICP-MS trace element chemistry for each DCT pumice group by Streck (unpublished).

\begin{tabular}{|c|c|c|c|c|c|c|}
\hline \multirow{2}{*}{$\begin{array}{l}\text { Group } \\
\text { Sample ID }\end{array}$} & \multirow{2}{*}{$\frac{\text { Group A }}{\text { DC11-1P }}$} & \multirow{2}{*}{$\frac{\text { Group B }}{\text { DC1133P8 }}$} & \multirow{2}{*}{$\frac{\text { Group C }}{10-28 D C-A}$} & \multicolumn{2}{|c|}{ Group D } & \multirow{2}{*}{$\frac{\text { Group E }}{\text { DC1133P11 }}$} \\
\hline & & & & DC1133P7 & DC1133P13 & \\
\hline \multicolumn{7}{|c|}{ ICP-MS (ppm) } \\
\hline $\mathrm{La}$ & 79.95 & 88.33 & 103.09 & 121.79 & 127.32 & 136.85 \\
\hline $\mathrm{Ce}$ & 188.02 & 195.39 & 196.32 & 242.11 & 244.19 & 262.26 \\
\hline $\operatorname{Pr}$ & 23.48 & 23.98 & 24.83 & 27.07 & 27.27 & 31.15 \\
\hline $\mathrm{Nd}$ & 95.47 & 96.61 & 97.48 & 101.34 & 102.09 & 124.03 \\
\hline $\mathrm{Sm}$ & 26.70 & 23.88 & 22.17 & 19.48 & 18.98 & 23.95 \\
\hline $\mathrm{Eu}$ & 0.71 & 0.76 & 0.80 & 0.76 & 0.95 & 2.15 \\
\hline Gd & 28.77 & 24.16 & 21.82 & 16.89 & 16.36 & 20.81 \\
\hline $\mathrm{Tb}$ & 5.39 & 4.36 & 3.83 & 2.81 & 2.61 & 3.38 \\
\hline Dy & 35.01 & 27.98 & 24.24 & 16.99 & 15.88 & 20.47 \\
\hline Но & 7.47 & 5.92 & 5.05 & 3.53 & 3.26 & 4.17 \\
\hline $\mathrm{Er}$ & 21.17 & 16.57 & 14.12 & 9.80 & 9.03 & 11.34 \\
\hline $\mathrm{Tm}$ & 3.14 & 2.47 & 2.11 & 1.45 & 1.37 & 1.70 \\
\hline $\mathrm{Yb}$ & 20.00 & 15.76 & 13.38 & 9.44 & 8.84 & 11.05 \\
\hline $\mathrm{Lu}$ & 3.12 & 2.52 & 2.17 & 1.55 & 1.46 & 1.89 \\
\hline $\mathrm{Ba}$ & 4 & 8 & 73 & 72 & 143 & 68 \\
\hline Th & 19.02 & 14.27 & 12.56 & 8.69 & 7.94 & 6.10 \\
\hline $\mathrm{Nb}$ & 103.74 & 81.15 & 69.01 & 49.41 & 45.92 & 62.72 \\
\hline Y & 192.63 & 151.00 & 128.22 & 87.71 & 80.18 & 102.13 \\
\hline $\mathrm{Hf}$ & 34.47 & 26.68 & 22.38 & 14.66 & 13.09 & 12.67 \\
\hline $\mathrm{Ta}$ & 6.67 & 5.02 & 3.86 & 2.86 & 2.67 & 3.28 \\
\hline $\mathrm{U}$ & 7.73 & 5.75 & 4.71 & 3.08 & 2.70 & 2.22 \\
\hline $\mathrm{Pb}$ & 43.01 & 30.31 & 19.61 & 17.67 & 16.39 & 15.98 \\
\hline $\mathrm{Rb}$ & 175.7 & 139.2 & 130.1 & 83.2 & 75.0 & 58.2 \\
\hline Cs & 5.94 & 4.12 & 3.46 & 2.16 & 1.92 & 1.27 \\
\hline $\mathrm{Sr}$ & 6 & 3 & 5 & 9 & 13 & 8 \\
\hline $\mathrm{Sc}$ & 0.2 & 0.1 & 5.2 & 0.4 & 0.6 & 0.6 \\
\hline $\mathrm{Zr}$ & 1603 & 1236 & 1063 & 680 & 589 & 547 \\
\hline
\end{tabular}




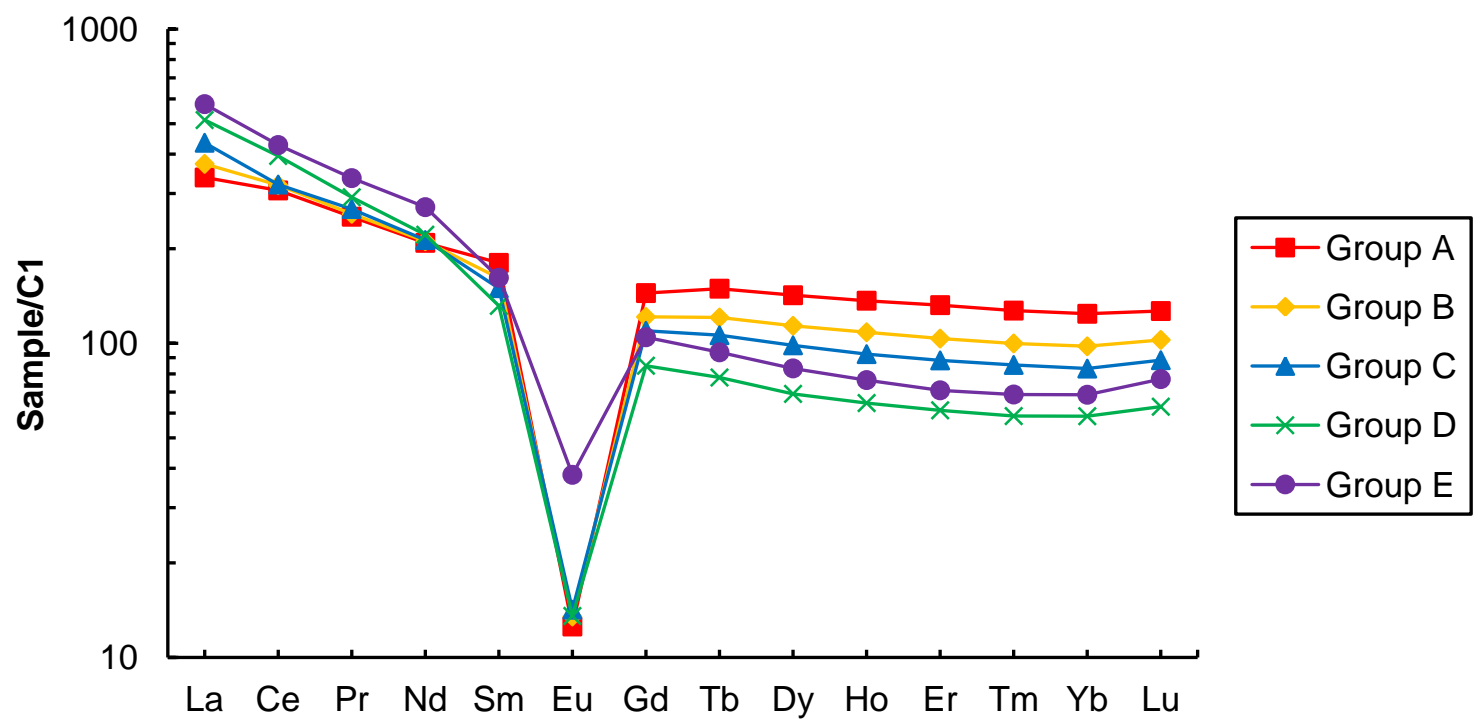

Figure 5. C1 chondrite normalized REE diagram for DCT pumice samples by group. A single representative pumice sample was selected from each group for graphing purposes. An overall negative slope and strong Eu anomaly is displayed by all groups, primarily due to the incorporation of Eu into feldspars. Group E displays the smallest Eu anomaly while groups A through D roughly overlap, suggesting crystal fractionation occurred between the generation of the dacite magma, $\mathrm{E}$, and the rhyolite magmas A through D. The depleted LREE relative to HREE can be attributed to the crystallization of chevkinite, a REE mineral with high LREE partition coefficients (Wolff et al., 2015).

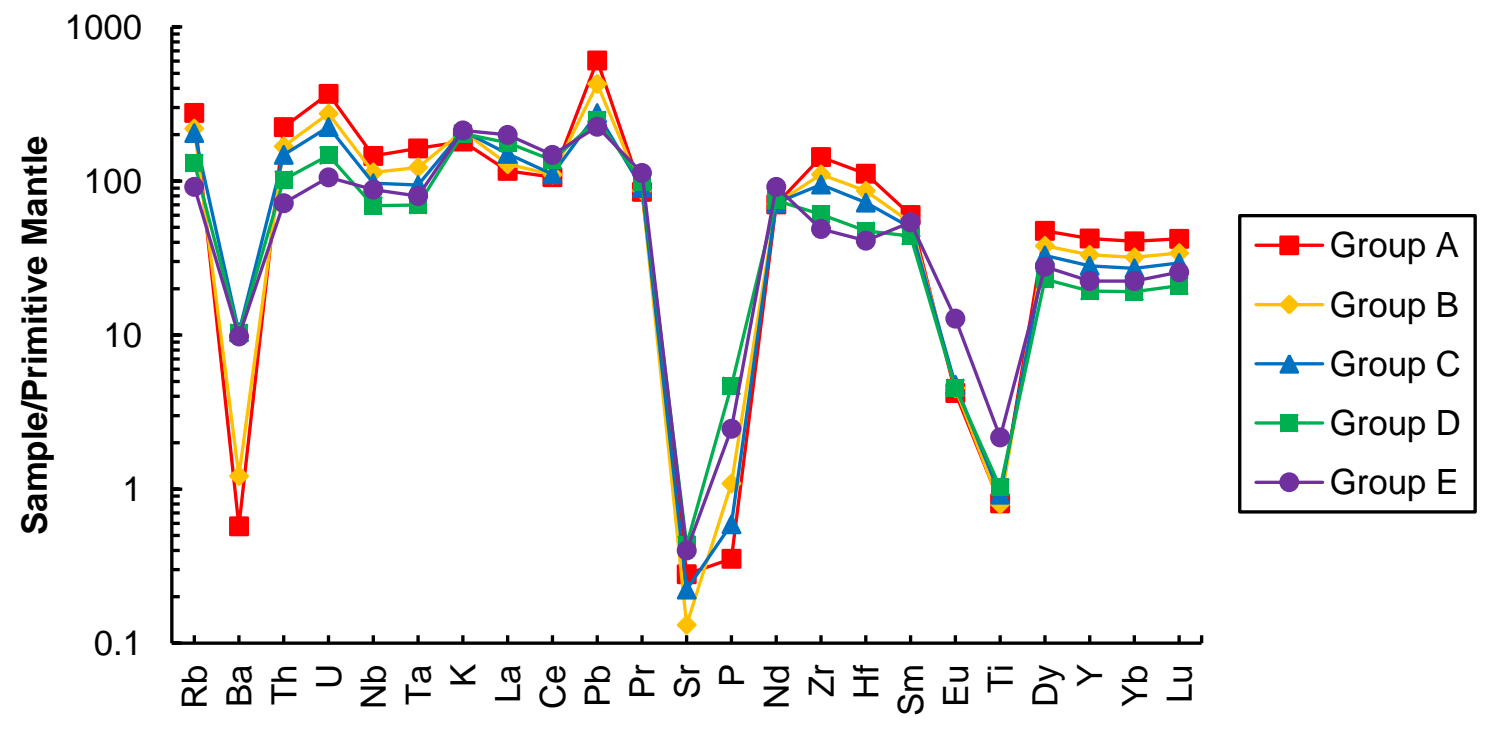

Figure 6. Primitive mantle normalized spider diagram for DCT pumice samples by group. All groups display an overall negative trend from the most incompatible elements to the least incompatible elements with troughs in $\mathrm{Ba}, \mathrm{Sr}, \mathrm{P}, \mathrm{Eu}$, and $\mathrm{Ti}$, likely due to their incorporation into mineral phases such as alkali feldspar (Ba, Eu), apatite (P), and oxides (Ti). 


\section{Sample Preparation}

The representative pumices selected from each group were disaggregated using a mortar and pestle, taking care to minimize fracturing the minerals present to preserve the original mineral morphology and size while removing embedded crystals from less durable pumiceous glass, and then sieved. Minimizing broken phenocrysts was important for preserving the natural size distribution and crystal habit of minerals within each pumice to prevent enrichment of finer size fractions with shattered crystal fragments. Therefore, crushing time and force was kept minimal, with only the coarsest portions being further disaggregated in the mortar and pestle until all pumiceous material passed through the largest $(<2000 \mu \mathrm{m})$ sieve mesh used. The intent during this step was to minimize broken phenocrysts while removing as much surrounding pumiceous material from crystals to preserve the original crystal size distribution within the DCT and allow for easy mineral identification using a binocular scope. For each group (with the exception of group A), an $25 \mathrm{~g}$ pumice material was crushed when possible or a larger pumice was selected and broken into a smaller sample to achieve the desired sample mass. Multiple smaller pumices were selected from the same outcrop and crushed together for group A, which consisted of lapilli-sized air-fall pumice, to obtain $\sim 25 \mathrm{~g}$ of material. When fragmenting larger pumices or using multiple smaller pumices, the individual portions were visually inspected to determine whether each pumice portion possessed similar crystal types, sizes, and distribution throughout to ensure the homogeneity of the sample. Each pumice sample was sieved into five particle size ranges: $<2000-991 \mu \mathrm{m},<991-425 \mu \mathrm{m},<425-125 \mu \mathrm{m}$, and $<125-104 \mu \mathrm{m}$, and $<104 \mu \mathrm{m}$. 
Any pumiceous material which did not pass through the $2000 \mu \mathrm{m}$ sieve was placed back into the mortar and pestle and crushed until all material was $<2000 \mu \mathrm{m}$ in diameter. All pumiceous material $<104 \mu \mathrm{m}$ was assumed to be vitric and confirmed for each sample with a visual inspection using a binocular microscope. For each pumice sample, every size fraction was weighed and compared to the initial mass of the pre-crushed sample to determine percent loss due to the loss of ash-sized particles while using the mortar and pestle and while sieving. To test the assumption of homogeneity within a sample, a $\sim 10 \mathrm{~g}$ duplicate was prepared for group $\mathrm{C}$ and subjected to the same physical analysis and compared with the results for the original group $\mathrm{C}$ pumice preparation. To test the homogeneity within a group, a separate $\sim 10 \mathrm{~g}$ sample was prepared for group $\mathrm{D}$ from another pumice belonging to the same group and compared to the initially prepared group D sample (samples DC1133P7 and DC1133P13; Table 1,Table 2, and Table 3). All pumiceous material was stored in individual glass vials divided into groups and subdivided into size fraction.

\section{Physical Analysis}

Each size fraction from the representative pumices of groups A through $\mathrm{E}$ were hand sorted using a binocular microscope and forceps into crystal and glass components and weighed. The crystalline components where then sorted into felsic and mafic minerals based on visual estimation, using color as the primary distinguishing factor between the felsic mineral phases such as alkali feldspar and quartz and the mafic mineral phases such as clinopyroxene, olivine, and Fe-Ti oxides, and then weighed. The felsic mineral phases were then further sorted into quartz and alkali feldspar, using crystal habit, conchoidal fracture, cleavage, and iridescence to differentiate between the two 
mineral phases. The $<125-104 \mu \mathrm{m}$ size fractions were too difficult to be sorted by hand using a binocular microscope due to the size of the particles and quantity of the material to manually sort. To obtain an approximate crystallinity, each $<125-104 \mu \mathrm{m}$ size fraction was homogenized to prevent any settling of mineral phases and ensure equal distribution of crystals and vitric material throughout the sample and ten $1 \mathrm{~mL}$ aliquots were taken and visually examined to estimate the crystallinity. These ten aliquots were then averaged and applied to the recorded mass for the size fraction to calculate the individual glass and crystal masses for each group (Table 4). The mass measurements of the crystal and glass components were used to calculate the crystallinity for each size fraction within a sample as well as the mass-weighted average crystallinity for each sample. All pumiceous material $<104 \mu \mathrm{m}$ was assumed to be entirely vitric and confirmed with a visual inspection for all five samples. Group E was unable to be hand sorted into felsic and mafic components due to the intergrowth of the mineral phases present (glomerocrystic texture), with felsic and mafic minerals often being unable to be separated, therefore the same physical breakdown by size fraction of glass and mineral components was not possible and omitted from this study. 
Table 4. $<125-104$ micron size fraction visual estimates of crystallinity.

\begin{tabular}{lccccccc}
\hline \hline Crystallinity (\%) & A & B & C & C duplicate & D & D duplicate & E \\
\hline Observation 1 & 6 & 9 & 11 & 8 & 15 & 13 & 40 \\
Observation 2 & 8 & 10 & 9 & 9 & 14 & 15 & 44 \\
Observation 3 & 5 & 8 & 8 & 7 & 16 & 13 & 42 \\
Observation 4 & 7 & 7 & 9 & 10 & 13 & 14 & 43 \\
Observation 5 & 5 & 10 & 10 & 9 & 16 & 15 & 40 \\
Observation 6 & 8 & 10 & 8 & 9 & 14 & 14 & 42 \\
Observation 7 & 6 & 7 & 9 & 8 & 13 & 15 & 43 \\
Observation8 & 7 & 9 & 10 & 10 & 16 & 13 & 44 \\
Observation 9 & 5 & 8 & 11 & 9 & 16 & 15 & 40 \\
Observation 10 & 5 & 10 & 9 & 7 & 15 & 13 & 40 \\
Average & 6.2 & 8.8 & 9.4 & 8.6 & 14.8 & 14 & 41.8 \\
\hline Note: the uncertainty for all visual estimates is $\pm 5 \%$ \\
\hline
\end{tabular}

The sorted and weighed felsic and mafic mineral phases for each size fraction within a sample were used to calculate the percent mafic crystals and percent felsic crystals which were further subdivided into percent quartz and percent feldspar. The generated data were then used in conjunction with the collected chemical data to examine the similarities and differences both within and between groups and establish the presence or absence of distinct crystal populations.

\section{Chemical Analysis}

Existing XRF and LA ICP-MS data for the DCT collected by Streck (unpublished) were used to supplement the chemical data collected during the course of this study for both bulk tuff and pumice samples. Individual mineral analyses were conducted for felsic and mafic minerals, primarily alkali feldspars and clinopyroxenes, using electron microprobe (EMP), scanning electron microscope (SEM), and laser ablation inductively coupled plasma mass spectrometry (LA ICP-MS) to evaluate compositional zonation within individual crystals, as well as compositional similarities and differences in minerals within and between groups. 


\section{Electron Microprobe}

Chemical analyses were conducted on both felsic and mafic mineral phases using a Cameca SX-100 electron microprobe at Oregon State University controlled remotely from Portland State University. Twenty alkali feldspars from each group were selected for analysis for 100 total feldspars, using crystals from the $<991-425 \mu \mathrm{m}$ size range, based upon the absence of any attached pumiceous material and lack of extensive breakage or alteration present. The selected feldspars were then mounted in resin and progressively polished to 1 micron grit for EMP analysis.

Mafic mineral phases were also mounted and polished using the same procedure. Due to paucity of mafic minerals relative to felsic minerals, which also varied widely (3 mafic minerals in Group B to 35 mafic minerals in Group E) between groups, the entirety of the mafic mineral phases sorted from each $\sim 25 \mathrm{~g}$ pumice sample were used for analysis. A total of 75 mafic minerals were mounted. A second mount of pyroxenes extracted from the $<125-104 \mu \mathrm{m}$ size fraction was also analyzed due to instrument malfunction during EMP analysis of the first mount.

The settings used for the electron microprobe were $15 \mathrm{nA}$ current for feldspar and $30 \mathrm{Na}$ current for mafic silicates, $15 \mathrm{kV}$ voltage, and a $2 \mu \mathrm{m}$ beam diameter. Elements analyzed were $\mathrm{Na}$ with a count time of $10+2 \times 5$ and a background condition of $\pm 800, \mathrm{Si}$ with a count time of $10+2 \times 5$ and a background condition of \pm 700, Al with a count time of $10+2 \times 5$ and a background condition of \pm 600 , Ca with a count time of $20+2 \times 5$ and a background condition of $\pm 500, \mathrm{~K}$ with a count time of $10+2 \times 5$ and a background condition of $\pm 700, \mathrm{Mg}$ with a count time of $10+2 \times 5$ and a background condition of 
\pm 1300, Fe with a count time of $10+2 \times 5$ and a background condition of \pm 500 , and Ba with a count time of $20+2 \times 5$ and a background condition of \pm 800 . Each crystal was analyzed from core to rim using 2-4 points per crystal (average of 2 points per crystal) to examine for evidence of zonation in composition, with important implications for the thermochemical environment from which each crystal nucleated. Due to time constraints, only 10 crystals (or if less than 10 crystals were present, then the total number of crystals within that group) per group were analyzed as well as oxide inclusions present with mafic mineral phases. The feldspars and mafic minerals were analyzed for $\mathrm{Na}_{2} \mathrm{O}, \mathrm{MgO}, \mathrm{Al}_{2} \mathrm{O}_{3}$, $\mathrm{SiO}_{2}, \mathrm{~K}_{2} \mathrm{O}, \mathrm{CaO}, \mathrm{FeO}$, and $\mathrm{BaO}$. The resulting feldspar and mafic mineral data were then normalized and used to calculate end member component compositions and generate element variation diagrams.

Scanning Electron Microscope

Scanning electron microscopy was conducted using a Zeiss Sigma VP FEG SEM at Portland State University. SEM was utilized to obtain both back scatter electron and energy dispersive electroscopy (EDS) data of mafic mineral phases from the $<991-425$ $\mu \mathrm{m}$ size fraction for all groups. EDS data collected using the SEM were used to classify the mafic mineral phases and composition of mineral inclusions hosted within mafic minerals.

Laser Ablation ICP-MS

LA ICP-MS was conducted using a Photon Machines Analyte G2 laser ablation system and a Thermo X-Series II ICP mass spectrometer at Oregon State University. Feldspar and pyroxene crystals were selected from all groups using the resin plug initially 
poured for the feldspars for EMP analysis. Difficulties in obtaining quality data using the EMP resulted in the original mafic mineral mount being discarded and the new mount being used. A second resin plug mounted with mafic minerals, which was also used for a second round of EMP analysis, was created using minerals from the $<125-104 \mu \mathrm{m}$ size fractions due to having used all $<991-425 \mu \mathrm{m}$ mafic minerals in the first plug used for EMP analysis. Thirty nine points were analyzed on 29 feldspar crystals and 46 points were analyzed for 33 mafic minerals, primarily clinopyroxenes. These single crystal data were used to supplement the chemical data obtained from EMP analysis. Trace element data from the LA ICP-MS were used to evaluate magma mixing as a viable mechanism to produce the range of trace element concentration observed within the DCT. 


\section{RESULTS}

The results of the DCT pumice analysis are broken into two categories. The first category consists of physical data measured from the crushing and sieving of pumices which consists of mass and crystallinity measurements for both crystal and glass components. The second category includes individual crystal chemical data collected from EMP and LA ICP-MS to supplement existing XRF and ICP-MS bulk tuff data from previous DCT studies (Streck, unpublished; Wacaster et al., 2011).

\section{Physical Data}

\section{Mass Measurements}

The crush and sieve mass measurements shown in Table 5 all display low percent errors from mass loss during the sieving process. The majority of sample loss is attributable to the loss of fines while sieving, primarily from the $<125-104 \mu \mathrm{m}$ and $<104$ $\mu \mathrm{m}$ size fractions which is more enriched in easily elutriated glass shards. However, as

demonstrated in Table 5, this loss of fines did not drastically affect the crystallinity of the $<125-104 \mu \mathrm{m}$ size fraction relative to other size fractions. The $<104 \mu \mathrm{m}$ size fraction was also assumed to be entirely vitric and confirmed by visual inspection of each sample, further reducing any impact from sample loss on the outcome of crystallinity and mineral proportionality measurements collected. The $<104 \mu \mathrm{m}$ size fraction, with the exception of group E, contained the most mass of all size fractions across all rhyolite groups which may represent enrichment from vitric material during the crushing process. The $<425-125$ $\mu \mathrm{m}$ size fraction contained the least mass across all groups, primarily due to the paucity of crystals which were within this size range (Table 6). 
Table 5. Crush and sieve measurement of initial pumice samples.

\begin{tabular}{lccccccc}
\hline \hline Size fraction & $\mathrm{E}(\mathrm{g})$ & $\mathrm{D}(\mathrm{g})$ & D duplicate $(\mathrm{g})$ & $\mathrm{C}(\mathrm{g})$ & $\mathrm{C}$ duplicate $(\mathrm{g})$ & $\mathrm{B}(\mathrm{g})$ & $\mathrm{A}(\mathrm{g})$ \\
\hline$<2000-991 \mu \mathrm{m}$ & 2.7 & 4.3 & 1.3 & 5.6 & 2.2 & 4.7 & 4.7 \\
$<991-425 \mu \mathrm{m}$ & 5.6 & 5.8 & 2.5 & 5.4 & 2.3 & 5.2 & 4.3 \\
$<425-125 \mu \mathrm{m}$ & 0.1 & 0.2 & 0.1 & 0.1 & 0.1 & 0.1 & 0.1 \\
$<125-104 \mu \mathrm{m}$ & 8.3 & 6.2 & 2.1 & 4.9 & 1.7 & 6.5 & 6.9 \\
$<104 \mu \mathrm{m}$ & 7.9 & 8.0 & 4.2 & 8.3 & 3.2 & 8.0 & 8.6 \\
Initial mass & 25.1 & 25.2 & 10.3 & 25.0 & 9.7 & 25.1 & 25.0 \\
Final mass & 24.6 & 24.5 & 10.2 & 24.3 & 9.5 & 24.5 & 24.6 \\
Mass difference & 0.5 & 0.7 & 0.1 & 0.7 & 0.2 & 0.6 & 0.4 \\
Sample loss $(\%)$ & 2.0 & 2.8 & 1.0 & 2.8 & 2.1 & 2.4 & 1.6 \\
\hline
\end{tabular}

Table 6. DCT crystal and glass masses by group.

\begin{tabular}{|c|c|c|c|c|c|c|c|}
\hline Size fraction & $\mathrm{E}(\mathrm{g})$ & $\mathrm{D}(\mathrm{g})$ & D duplicate $(\mathrm{g})$ & $\mathrm{C}(\mathrm{g})$ & C duplicate $(\mathrm{g})$ & $\mathrm{B}(\mathrm{g})$ & $\mathrm{A}(\mathrm{g})$ \\
\hline \multicolumn{8}{|l|}{$\leq 2000-991 \mu \mathrm{m}$} \\
\hline Crystal mass & 0.2081 & 0.9827 & 0.2179 & 0.0808 & 0.0280 & 0.1921 & 0.0702 \\
\hline Glass mass & 2.5501 & 3.3337 & 1.1403 & 5.5167 & 2.186 & 4.4601 & 4.6274 \\
\hline Mass sum & 2.7582 & 4.3164 & 1.3582 & 5.5975 & 2.2140 & 4.6522 & 4.6976 \\
\hline Crystallinity (\%) & 7.54 & 22.77 & 16.04 & 1.44 & 1.26 & 4.13 & 1.49 \\
\hline \multicolumn{8}{|l|}{$<991-425 \mu \mathrm{m}$} \\
\hline Crystal mass & 1.7430 & 2.5686 & 0.9269 & 0.8996 & 0.3510 & 0.9384 & 0.2733 \\
\hline Glass mass & 3.8390 & 3.2021 & 1.5176 & 4.3912 & 1.902 & 4.2292 & 3.9678 \\
\hline Mass sum & 5.5820 & 5.7707 & 2.4445 & 5.2908 & 2.2530 & 5.1676 & 4.2411 \\
\hline Crystallinity (\%) & 31.23 & 44.51 & 37.92 & 17.00 & 15.58 & 18.16 & 6.44 \\
\hline \multicolumn{8}{|l|}{$\leq 425-125 \mu \mathrm{m}$} \\
\hline$\overline{\text { Crystal mass }}$ & 0.0723 & 0.0425 & 0.0147 & 0.0177 & 0.0060 & 0.0228 & 0.0048 \\
\hline Glass mass & 0.1052 & 0.1635 & 0.0215 & 0.1131 & 0.028 & 0.1298 & 0.1110 \\
\hline Mass sum & 0.1775 & 0.2060 & 0.0362 & 0.1308 & 0.0340 & 0.1526 & 0.1158 \\
\hline Crystallinity (\%) & 40.73 & 20.63 & 40.61 & 13.53 & 17.65 & 14.94 & 4.15 \\
\hline \multicolumn{8}{|l|}{$\leq 125-104 \mu \mathrm{m}$} \\
\hline$\overline{\text { Crystal mass }}$ & 3.4230 & 0.9012 & 0.2865 & 0.4420 & 0.1534 & 0.5571 & 0.4078 \\
\hline Glass mass & 4.7660 & 5.1878 & 1.7598 & 4.2600 & 1.631 & 5.7739 & 6.1702 \\
\hline Mass sum & 8.189 & 6.089 & 2.046 & 4.702 & 1.784 & 6.331 & 6.578 \\
\hline Crystallinity (\%) & 41.80 & 14.80 & 14.00 & 9.40 & 8.60 & 8.80 & 6.20 \\
\hline \multicolumn{8}{|l|}{$<104 \mu \mathrm{m}$} \\
\hline Glass mass & 7.862 & 7.950 & 4.190 & 8.223 & 3.107 & 8.128 & 8.505 \\
\hline Total glass mass & 19.122 & 19.837 & 8.629 & 22.504 & 8.854 & 22.721 & 23.381 \\
\hline Total crystal mass & 5.446 & 4.495 & 1.446 & 1.440 & 0.538 & 1.710 & 0.756 \\
\hline Total sample mass & 24.569 & 24.332 & 10.075 & 23.944 & 9.392 & 24.431 & 24.138 \\
\hline Total crystallinity (\%) & 22.17 & 18.47 & 14.35 & 6.01 & 5.73 & 7.00 & 3.13 \\
\hline
\end{tabular}




\section{Crystallinity}

All groups exhibit an increase in crystallinity from the coarsest size fraction to the $<991-425 \mu \mathrm{m}$ size fraction, which displays the greatest crystallinity of all size fractions for all groups except the groups $\mathrm{C}$ and $\mathrm{D}$ duplicates (Table 6 and Table 7; Figure 7). All groups demonstrate an overall decrease in crystallinity of varying proportions from the $<991-425 \mu \mathrm{m}$ to the $<125-104 \mu \mathrm{m}$ size fraction, with the exception of group $\mathrm{E}$ which has an overall positive trend in crystallinity with progressively finer size fractions. Group D also displays a different pattern than the other samples, while still following the general observations detailed above. Group E displays the most contrasting trend in crystallinity with size fraction, with an increase in crystallinity from the coarsest to finest size fraction, a pattern not observed in any of the rhyolite pumices. However, the duplicate for group D exhibits an elevated crystal fractions between $<425-125 \mu \mathrm{m}$ more consistent with group E. While group D may also have a greater crystallinity than any other group for the $<2000-991 \mu \mathrm{m}$ and $<991-425 \mu \mathrm{m}$ size fractions, the overall increase from the coarsest to second coarsest size factions is similar to the other rhyolite groups, despite the overall crystallinity pattern exhibited by group D being appreciably different from all other groups.

Table 7. DCT crystallinity and total crystallinity by group.

\begin{tabular}{lccccccc}
\hline \hline Size fraction & $\mathrm{E}(\%)$ & $\mathrm{D}(\%)$ & D duplicate $(\%)$ & $\mathrm{C}(\%)$ & $\mathrm{C}$ duplicate $(\%)$ & $\mathrm{B}(\%)$ & $\mathrm{A}(\%)$ \\
\hline$<2000-991 \mu \mathrm{m}$ & 7.54 & 22.77 & 16.04 & 1.44 & 1.26 & 4.13 & 1.49 \\
$<991-425 \mu \mathrm{m}$ & 31.23 & 44.51 & 37.92 & 17.00 & 15.58 & 18.16 & 6.44 \\
$<425-125 \mu \mathrm{m}$ & 40.73 & 20.63 & 40.61 & 13.53 & 17.65 & 14.94 & 4.15 \\
$<125-104 \mu \mathrm{m}$ & 41.80 & 14.80 & 14.00 & 9.40 & 8.60 & 8.80 & 6.20 \\
Mass weighted & & & & & & & \\
average crystallinity & 22.17 & 18.47 & 14.35 & 6.01 & 5.73 & 7.00 & 3.13 \\
\hline
\end{tabular}


Between groups, an overall trend of decreasing average crystallinity is displayed from group E to group A, as shown in Table 7 and Figure 7. Group E is appreciably different in crystallinity, and therefore displays a pattern different from the rhyolite samples in groups A through D. The $<2000-991 \mu \mathrm{m}$ size fractions had the overall lowest crystallinity with the exception of group $\mathrm{D}$, whose $<125-104 \mu \mathrm{m}$ size fraction was less crystalline. Between $<911$ and $>125 \mu \mathrm{m}$ is the dominant mineral size within all groups except group E. As shown in Figure 7, Group E displays a progressively increasing crystallinity with decreasing size fraction and is the most crystal-rich of all groups with the exception of group D with a pattern that is distinctly different from those exhibited by the rhyolite pumices.

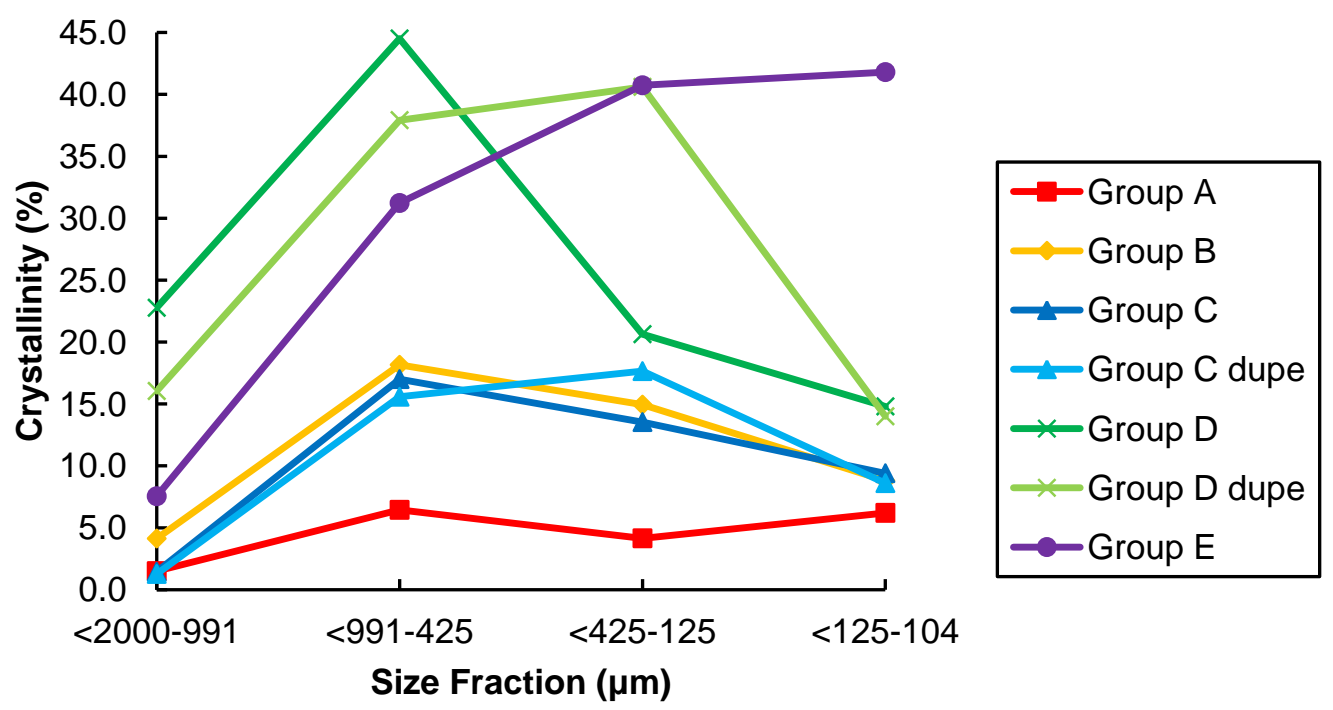

Figure 7. Percent crystallinity of each size fraction by group. Group E exhibits an increase in crystallinity with progressively finer size fractions, in contrast to all other groups which typically display a decrease in crystallinity with finer size fractions.

The $<125-104 \mu \mathrm{m}$ size fraction was not manually sorted due to the size of the crystals but rather 10 visual estimates were made and averaged of the overall crystallinity of the size fraction and utilized to calculate the percent crystallinity using the mass of the 
size fraction. All groups can be divided into four patterns based on the data from Figure 7. Group $\mathrm{E}$, the dacite, is unique in displaying an increasing crystallinity with decreasing size fraction, as well as having the highest overall crystallinity (with the exception of group D) and steepest positive slope. Group D and its duplicate also display the steep positive slope exhibited by group E from the $<2000-991$ to $<991-425 \mu \mathrm{m}$ size fractions and greatest overall crystallinity at the $<991-425 \mu \mathrm{m}$ size range, however, group D also has the greatest decrease in crystallinity from the $<425-125$ to the $<125-104 \mu \mathrm{m}$ size fractions. Groups B, C, and C duplicate all closely mirror the same pattern, with a moderate increase from the coarsest size fraction with a gradual decrease to the finest size fraction. Lastly, group A exhibits the flattest slope of all pumices, with the least variance in crystallinity between each size fraction. When comparing only the rhyolites and excluding the dacite, an overall shift from steep positive increases in crystallinity from the coarsest towards the middle size fractions coupled with a steep negative decrease in crystallinity towards the finest size fractions can be observed in group D and its duplicate which progressively becomes less steep until the more muted pattern of group A is produced. A trend of decreasing crystallinity from the least evolved rhyolite group to the most evolved rhyolite group is observed. 
Table 8. Crystallinity subdivided into felsic and mafic proportions by rhyolite group.

\begin{tabular}{|c|c|c|c|c|c|c|}
\hline Size fraction & $\mathrm{D}(\%)$ & D duplicate $(\%)$ & $\mathrm{C}(\%)$ & $\mathrm{C}$ duplicate $(\%)$ & $\mathrm{B}(\%)$ & $\mathrm{A}(\%)$ \\
\hline \multicolumn{7}{|l|}{$<2000-991 \mu \mathrm{m}$} \\
\hline Felsic & 99.8 & 97.5 & 100.0 & 100.0 & 100.0 & 87.3 \\
\hline Quartz & 46.4 & 50.3 & 56.3 & 89.3 & 82.2 & 48.0 \\
\hline Feldspar & 53.4 & 47.2 & 43.8 & 10.7 & 17.8 & 39.3 \\
\hline $\begin{array}{l}\text { Mafic } \\
\leq 991-425 \mu \mathrm{m}\end{array}$ & 0.2 & 2.5 & 0.0 & 0.0 & 0.0 & 12.7 \\
\hline Felsic & 95.5 & 92.4 & 99.9 & 99.7 & 99.5 & 98.1 \\
\hline Quartz & 63.3 & 47.8 & 64.6 & 53.6 & 56.7 & 70.2 \\
\hline Feldspar & 32.2 & 44.5 & 35.3 & 46.2 & 42.8 & 27.9 \\
\hline $\begin{array}{l}\text { Mafic } \\
\leq 425-125 \mu \mathrm{m}\end{array}$ & 4.5 & 7.6 & 0.1 & 0.3 & 0.5 & 1.9 \\
\hline Felsic & 97.0 & 95.2 & 100.0 & 100.0 & 99.2 & 95.3 \\
\hline Quartz & 58.7 & 32.7 & 66.7 & 66.7 & 69.0 & 47.7 \\
\hline Feldspar & 38.3 & 62.6 & 33.3 & 33.3 & 30.2 & 47.7 \\
\hline Mafic & 3.0 & 4.8 & 0.0 & 0.0 & 0.8 & 4.7 \\
\hline
\end{tabular}

Due to the glomercrystic texture of the minerals present within group E, the dacite sample, the individual mineral components were not able to be sorted manually or visually estimated due to the amount of crystal intergrowth.

All rhyolite samples dominated by felsic minerals with $>92 \%$ total felsic crystals per group (Table 8). The dominant mineral observed was quartz with the exception of the group D duplicate $<425-125 \mu \mathrm{m}$ size fraction, where feldspar was the dominant mineral, representing $62.59 \%$ of the total crystallinity for that size fraction. Quartz ranged from 32.65-82.20\% (when removing the single outlier value, the range becomes 46.36-82.20 $\%$ ) of each groups total minerals per size fraction. There is an overall increase in quartz percentages towards the more evolved rhyolites across all size fractions, with the exception of the group A $<2000-991 \mu \mathrm{m}$ size fraction where roughly equal proportions of large quartz and feldspar phenocrysts (1-2 mm) were found. Many of the quartz phenocrysts were subhedral to euhedral with some evidence for resorption displayed by the pitted crystal faces. 
Overall mafic crystallinity was low with $<7.65 \%$, across all rhyolite groups.

Mafic mineral phases were primarily concentrated in the $<991-425 \mu \mathrm{m}$ size fraction. Mafic minerals were typically few, but can also occur as large phenocrysts when found in the $<2000-991 \mu \mathrm{m}$ size fraction, with the observed percentages representing 1-3 crystals.

\section{Chemical Data}

\section{Feldspars}

Major elements

Feldspars analyzed by EMP displayed little chemical variation among major elements, both between crystals within each group (Table 9) and each core-rim analysis pair per individual crystal, suggesting little to no compositional zonation of feldspars. $\mathrm{K}_{2} \mathrm{O}$ increases while $\mathrm{CaO}$ decreases when moving from the dacite group, $\mathrm{E}$, to the rhyolites groups, A through D. However, $\mathrm{FeO}^{*}$ (total iron present in all oxidation states) does not display the same pattern as $\mathrm{CaO}$, instead $\mathrm{FeO}^{*}$ has a peak concentration in group $\mathrm{C}$ and decreases towards both group $\mathrm{E}$ and $\mathrm{A} . \mathrm{MgO}$ was beneath the detection limit for all groups and therefore not reported.

Table 9. Average weight percent EMP major element feldspar chemical composition by group.

\begin{tabular}{lccccccc}
\hline $\begin{array}{l}\text { Group } \\
\text { (wt. \%) }\end{array}$ & $\mathrm{SiO}_{2}$ & $\mathrm{Al}_{2} \mathrm{O}_{3}$ & $\mathrm{FeO} *$ & $\mathrm{CaO}$ & $\mathrm{Na}_{2} \mathrm{O}$ & $\mathrm{K}_{2} \mathrm{O}$ & $\mathrm{BaO}$ \\
\hline $\mathrm{A}$ & 67.2 & 19.0 & 0.29 & 0.09 & 6.3 & 7.2 & 0.02 \\
$\mathrm{~B}$ & 67.2 & 18.8 & 0.37 & 0.03 & 6.2 & 7.4 & 0.01 \\
$\mathrm{C}$ & 66.1 & 18.5 & 0.43 & 0.05 & 6.1 & 8.8 & 0.01 \\
$\mathrm{D}$ & 67.2 & 18.9 & 0.36 & 0.06 & 6.2 & 7.3 & 0.01 \\
$\mathrm{E}$ & 66.7 & 19.7 & 0.18 & 0.65 & 6.8 & 5.9 & 0.07 \\
\hline
\end{tabular}


Table 10. Average feldspar end member component composition by group.

\begin{tabular}{llll} 
Group (\%) & An & \multicolumn{1}{c}{ Ab } & Or \\
\hline A & 0.47 & 56.97 & 42.56 \\
$\pm \sigma$ & 0.2 & 0.79 & 0.92 \\
B & 0.17 & 55.95 & 43.88 \\
$\pm \sigma$ & 0.1 & 0.59 & 0.56 \\
C & 0.01 & 55.90 & 44.09 \\
$\pm \sigma$ & 0 & 0.82 & 0.82 \\
D & 0.32 & 56.06 & 43.62 \\
$\pm \sigma$ & 0.2 & 0.87 & 0.85 \\
E & 3.24 & 61.52 & 35.24 \\
$\pm \sigma$ & 1.7 & 3.26 & 4.7 \\
\hline
\end{tabular}

All feldspars are grouped very closely compositionally except for group E as shown in Figure 8 and Figure 9. Groups A through D all range between 55.9-56.9 average $\mathrm{Ab} \%$ and $42.5-44.0$ average Or $\%$ with $<1 \%$ An (Table 10). Group E is compositionally distinct with a $\sim 4 \%$ increase $\mathrm{Ab}, \mathrm{a} \sim 3 \%$ increase in $\mathrm{An}$, and a $\sim 10 \%$ decrease Or component, however, this can be attributed to the wide range of feldspar compositions composing group E as shown in Figure 8.

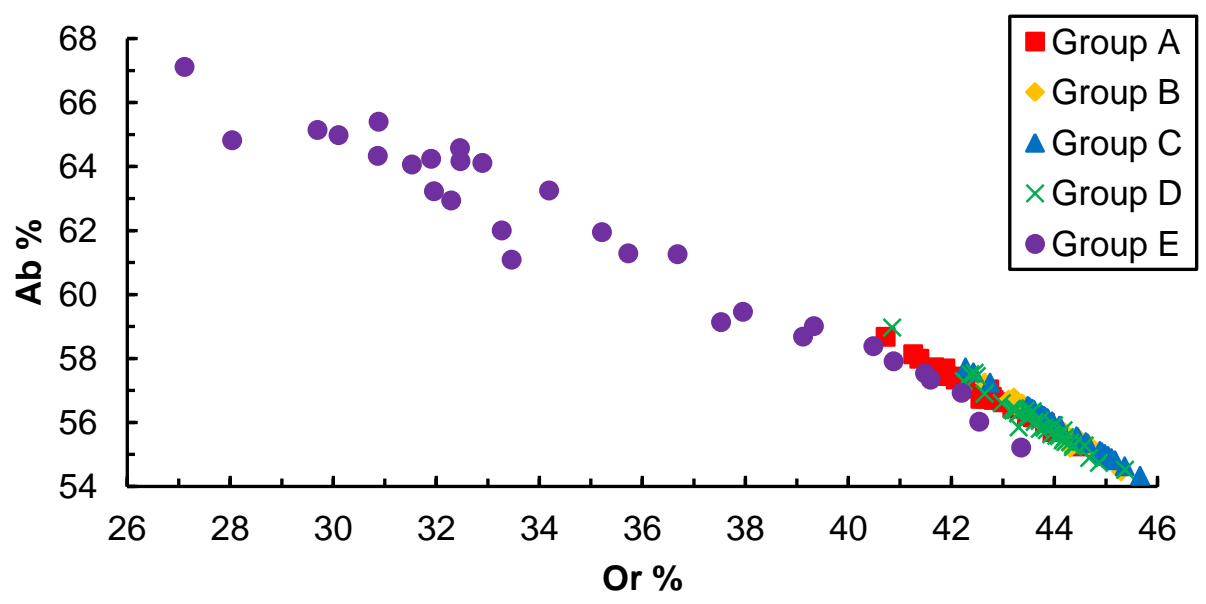

Figure 8. Ab vs. Or ternary feldspar end member components by group using EMP data. All groups fall along the same negative slope from the dacite, group E, to groups A through D which cluster tightly together from $40-46 \%$ Or. 


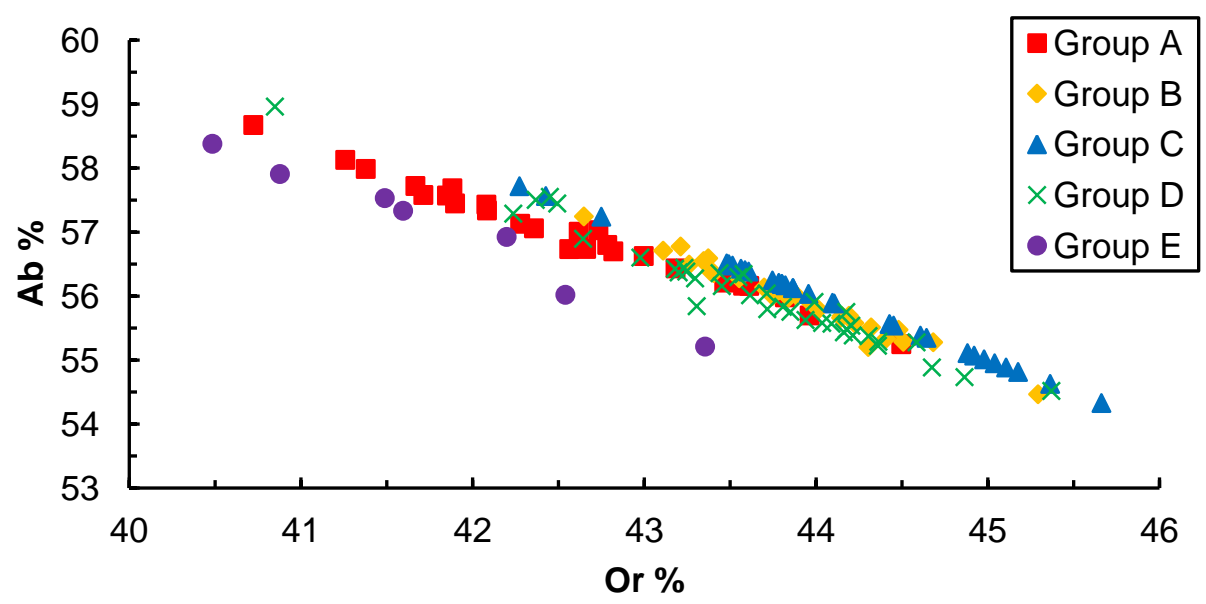

Figure 9. Ab vs. Or feldspar end member components zoomed in on clustered data from Figure 8. Feldspars sampled from the dacite pumice, group $E$, still fall within the range of values displayed by the high silica rhyolites of groups A-D. The most potassium rich feldspars ranging from $\mathbf{4 5 - 4 5 \%}$ Or occur in groups B through D, which excludes the air fall pumice unit that comprises group $A$.

Within the DCT dacite and rhyolite units examined there are two populations of crystals with shared origins. The first population of feldspars belonging to the rhyolite groups A through $\mathrm{D}$ have a relatively homogenous bulk composition that reflects increasing Or \% with more evolved rhyolite magmas, with the important exception of group A (air fall pumice unit), and trace element concentrations which overlap but form distinct clusters of data between groups A through D. A second population of feldspars is present within group $\mathrm{E}$, the dacite, which have a higher $\mathrm{Ab} \%$ and display a wide range of $\mathrm{Na}_{2} \mathrm{O}$ and $\mathrm{K}_{2} \mathrm{O}$ concentrations when compared with the feldspars found in the rhyolite groups. This second population of feldspars also exhibit zonation with an increase of $\sim 1 \% \mathrm{~K}_{2} \mathrm{O}$ wt. \% from core to rim which the rhyolite groups lack and a wide spread of trace element concentrations which form a loose cluster. 


\section{Trace elements}

There was a wide range of concentrations for trace elements within groups for single feldspar crystals as shown in Table 11 and Figures 10-13. Group E was enriched in $\mathrm{Ti}, \mathrm{Mn}, \mathrm{Sr}, \mathrm{Ba}$, and Eu relative to the rhyolite groups, whereas the rhyolite groups were enriched in $\mathrm{Rb}$. Ti varied significantly for all groups with $>20$ standard deviations from the average value for each group. $\mathrm{Rb}$ and $\mathrm{Sr}$ were $>2$ standard deviations except for group D while $\mathrm{Ba}$ was $>6$ standard deviations except for group $\mathrm{C}$ where is it was 2.91 standard deviations from the average value. All other elements were below or slightly above 1 standard deviation from the average value with a narrow range of concentrations.

Table 11. Averaged group LA ICP-MS feldspar trace element data.

\begin{tabular}{lcccccccccc}
\hline \hline Conc. (ppm) & $\mathrm{A}$ & $\pm \sigma$ & $\mathrm{B}$ & $\pm \sigma$ & $\mathrm{C}$ & $\pm \sigma$ & $\mathrm{D}$ & $\pm \sigma$ & $\mathrm{E}$ & $\pm \sigma$ \\
\# of analyses & 8 & & 7 & & 8 & & 8 & & 7 & \\
\hline $\mathrm{Sc}$ & 7.14 & 0.25 & 6.89 & 0.35 & 7.03 & 0.18 & 6.66 & 0.22 & 6.60 & 0.36 \\
$\mathrm{Ti}$ & 70.95 & 23.81 & 56.92 & 23.20 & 44.58 & 2.71 & 43.17 & 2.55 & 266.10 & 20.50 \\
$\mathrm{~V}$ & & & & & 0.03 & & & & 0.05 & \\
$\mathrm{Mn}$ & 0.93 & 0.29 & 0.76 & 0.45 & 0.62 & 0.21 & 0.97 & 0.21 & 2.95 & 1.09 \\
$\mathrm{Zn}$ & 4.27 & 0.49 & 4.93 & 1.03 & 5.50 & 0.59 & 5.41 & 0.78 & 3.40 & 0.49 \\
$\mathrm{Rb}$ & 30.02 & 2.77 & 47.47 & 12.11 & 52.67 & 8.97 & 35.56 & 2.64 & 16.31 & 2.81 \\
$\mathrm{Sr}$ & 7.81 & 4.27 & 2.26 & 3.24 & 0.76 & 1.02 & 2.76 & 1.84 & 31.94 & 18.05 \\
$\mathrm{Y}$ & & & & & & & & & 0.23 & 0.17 \\
$\mathrm{Zr}$ & & & 0.55 & & & & & & 0.32 & 0.20 \\
$\mathrm{Nb}$ & & & & & & & & & 0.09 & \\
$\mathrm{Ba}$ & 88.72 & 92.25 & 38.92 & 60.74 & 5.17 & 2.91 & 8.94 & 6.07 & 741.19 & 547.83 \\
$\mathrm{La}$ & 0.23 & 0.25 & 0.18 & 0.11 & 0.06 & 0.02 & 0.07 & 0.00 & 2.06 & 0.31 \\
$\mathrm{Ce}$ & 0.21 & 0.20 & 0.11 & 0.09 & 0.06 & 0.01 & 0.05 & 0.03 & 1.98 & 0.35 \\
$\mathrm{Pr}$ & & & & & & & & & 0.11 & 0.03 \\
$\mathrm{Nd}$ & & & & & & & & & 0.43 & 0.04 \\
$\mathrm{Eu}$ & 0.68 & 0.27 & 0.22 & 0.21 & 0.14 & 0.08 & 0.28 & 0.10 & 5.59 & 1.32 \\
$\mathrm{~Pb}$ & 2.12 & 0.14 & 1.83 & 0.15 & 1.96 & 0.17 & 2.18 & 0.18 & 3.28 & 0.67 \\
\hline
\end{tabular}

As shown in Figures 10-13, feldspars form two loose clusters of data with group E forming a distinct grouping of points while groups A through D display overlap between rhyolite groups. Group E feldspars largely do not overlap with feldspars from the rhyolite groups. Group A, the air fall pumice, does not represent the most enriched 
feldspar composition despite having the most evolved bulk composition, instead, groups

$\mathrm{B}$ and $\mathrm{C}$ represent the pumices that were most enriched in incompatible trace elements.

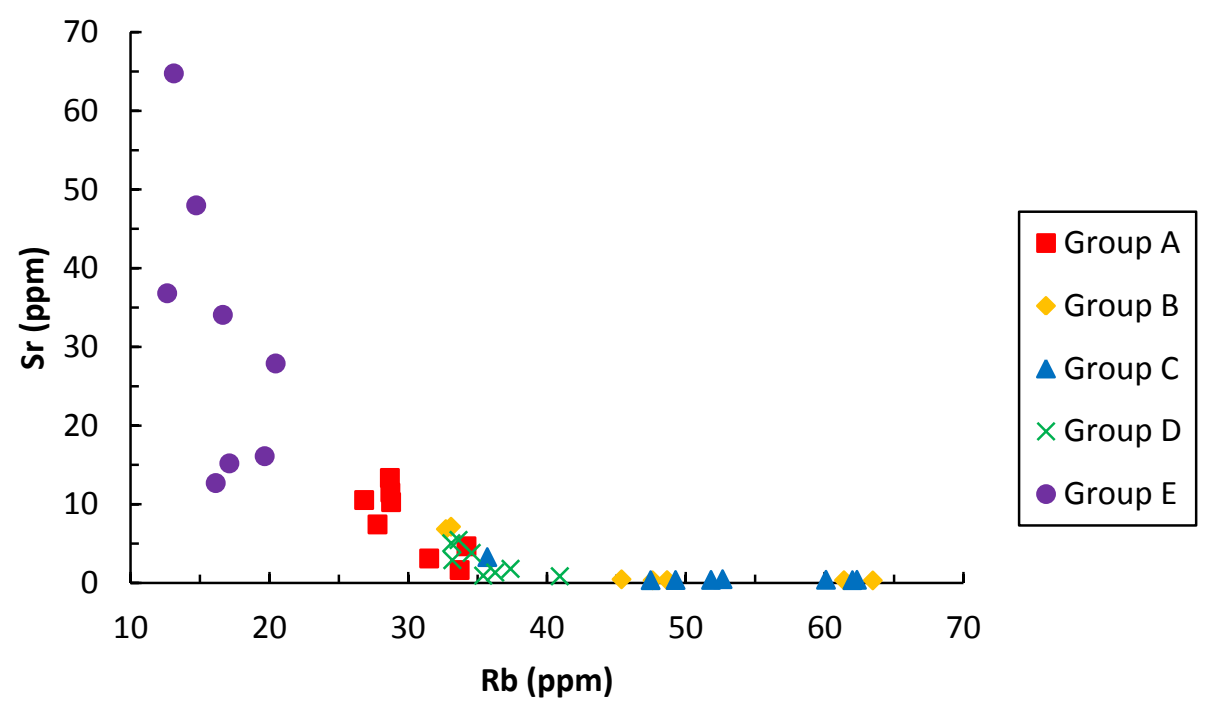

Figure 10. Rb vs. Sr in ppm in feldspars using LA ICP-MS data. Sr is typically incorporated into plagioclase crystals while $\mathrm{Rb}$ remains in the melt. Group $\mathrm{E}$ has the widest range of $\mathrm{Sr}$ concentrations that decreases with increasing $\mathrm{Rb}$ and forms a loose cluster with no overlap with the rhyolite groups. Group $\mathrm{A}$ is the least enriched in $\mathbf{R b}$ among rhyolite groups. There is overlap between groups $\mathrm{B}$ through D, however, groups B and C form discrete clusters at higher Rb concentrations. 


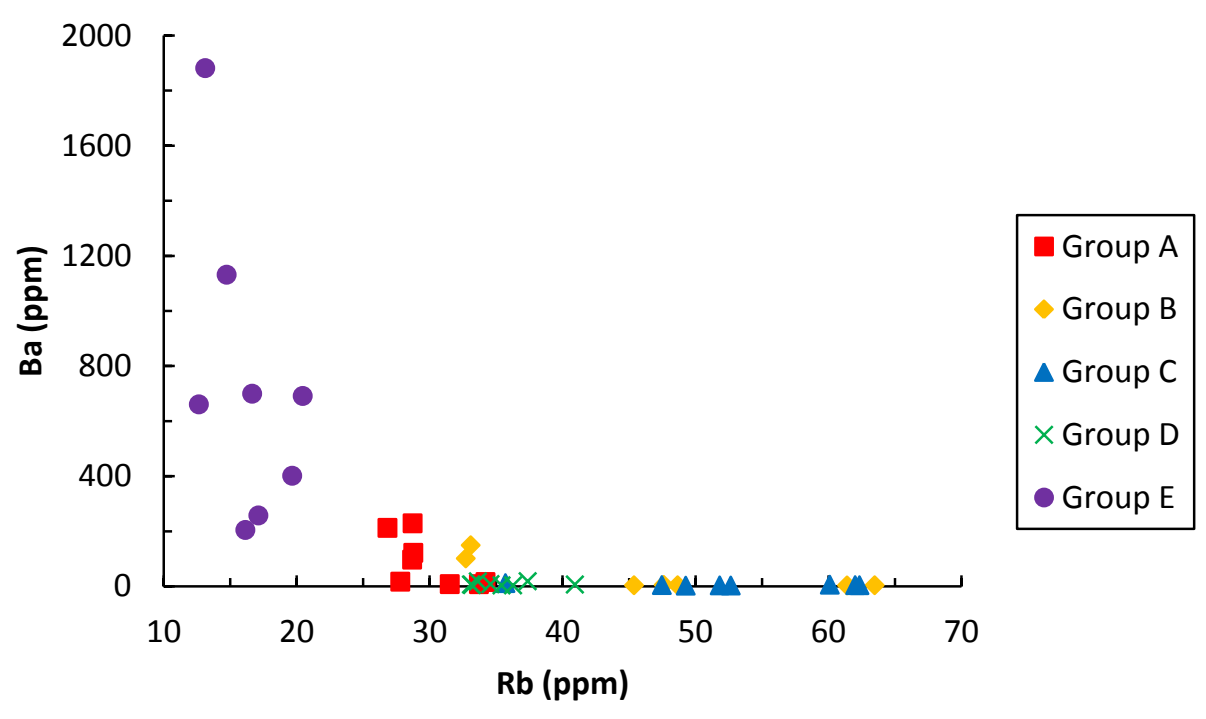

Figure 11. Rb vs. Ba in ppm in feldspars using LA ICP-MS data. Ba serves as a substitute for $\mathrm{K}$ in alkali feldspars. A similar pattern is observed from Figure 10 where $E$ forms a loose cluster, $A$ is the least enriched in $\mathrm{Rb}$ when compared to the other rhyolites, and groups $\mathrm{D}$ and $\mathrm{C}$ are the most enriched in $\mathbf{R b}$ and form clusters of data at higher $\mathbf{R b}$ values.

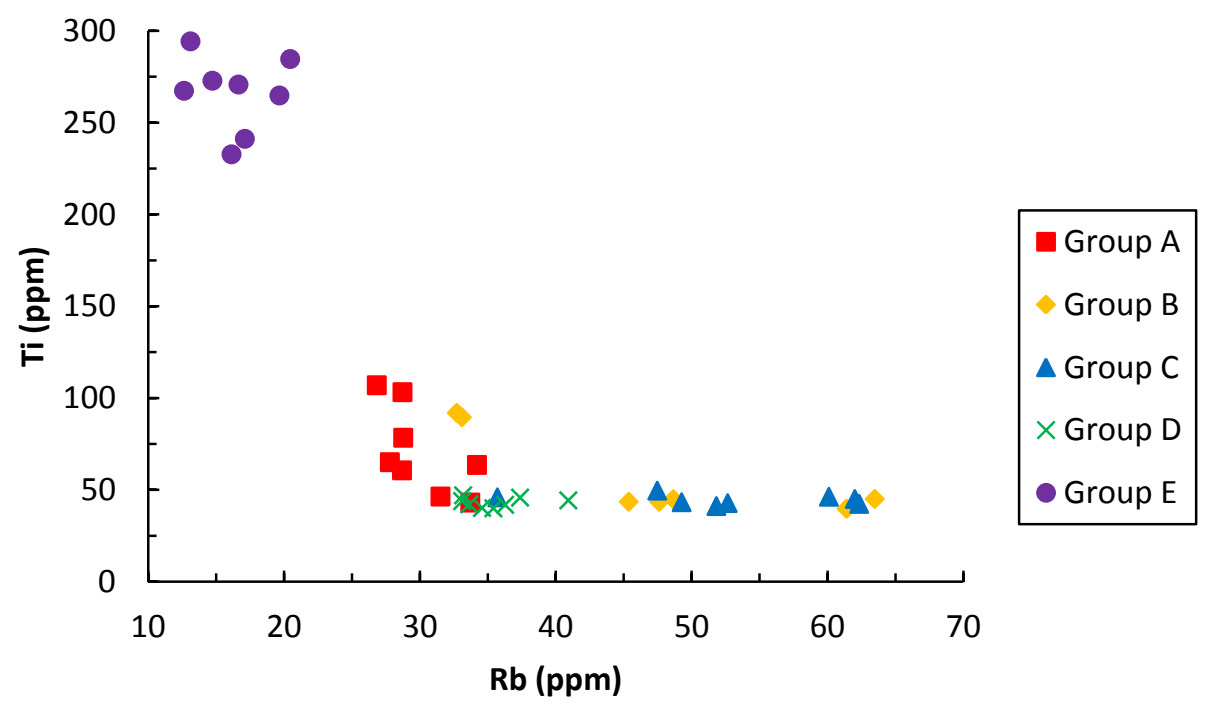

Figure 12. Rb vs. Ti in ppm in feldspars using LA ICP-MS data. Group E forms a discrete cluster at high Ti concentrations with a greater separation observed than with $\mathrm{Sr}$ or Ba. Group A is displays the second lowest $\mathrm{Rb}$ concentrations and second highest Ti concentrations. There is an overlap between groups $A$ through $D$ while groups $B$ and $C$ once again display two clusters of data at $\sim 50$ and $\sim 60 \mathrm{ppm}$ Rb. 


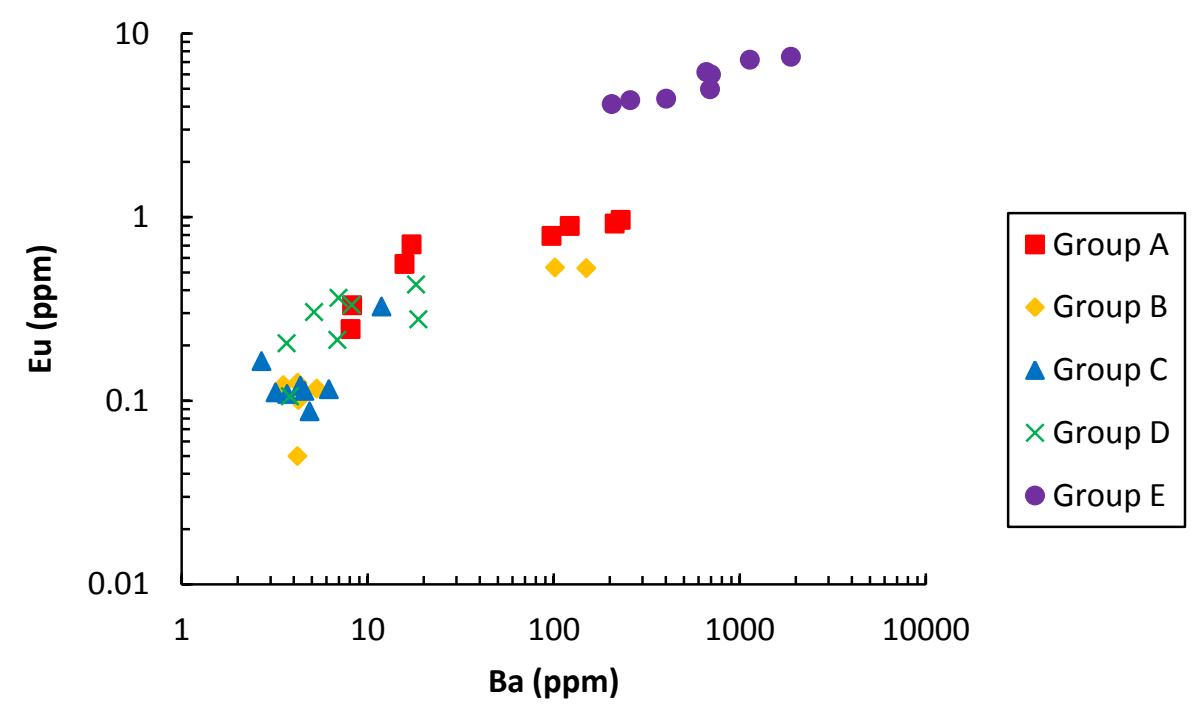

Figure 13. Ba vs. Eu in ppm in feldspars using LA ICP-MS data in a log-log plot. Once more, group $E$ forms a distinct cluster at higher Ba and Eu concentrations. Group $A$ is the most enriched in Ba and Eu amongst the rhyolite groups. A subset of crystals from groups A and B form a more enriched concentration cluster separate from the remaining rhyolite groups which form a third, least enriched cluster.

Pyroxenes

\section{Major elements}

The major element chemistry for clinopyroxenes is consistent across all groups as shown in Table 12. The dacite group displays higher $\mathrm{TiO}_{2}, \mathrm{Al}_{2} \mathrm{O}_{3}, \mathrm{MnO}$, and $\mathrm{CaO}$ and lower $\mathrm{Na}_{2} \mathrm{O}$ when compared with the rhyolite groups, otherwise the major element compositions show little variation between groups. Group B clinopyroxenes have the highest average $\mathrm{MgO}$ concentration of all groups. All observed clinopyroxenes in the DCT are Fe-rich in composition. Also, several outlier ortho- and clinopyroxenes not consistent with those observed in the dacite and rhyolites were observed as shown in Figure 14 and may represent xenocrysts. 
Table 12. Average weight percent EMP clinopyroxene chemical composition by group.

\begin{tabular}{lcccccccccc}
\hline \hline $\begin{array}{l}\text { Group } \\
\text { (wt. \%) }\end{array}$ & $\mathrm{SiO}_{2}$ & $\mathrm{TiO}_{2}$ & $\mathrm{Al}_{2} \mathrm{O}_{3}$ & $\mathrm{FeO}$ & $\mathrm{MnO}$ & $\mathrm{MgO}$ & $\mathrm{CaO}$ & $\mathrm{Na}_{2} \mathrm{O}$ & $\mathrm{Cr}_{2} \mathrm{O}_{3}$ & $\mathrm{ZnO}$ \\
\hline $\mathrm{A}$ & 48.9 & 0.27 & 0.16 & 30.5 & 1.14 & 0.22 & 17.9 & 0.78 & 0.01 & 0.11 \\
$\mathrm{~B}$ & 48.2 & 0.33 & 0.21 & 30.2 & 1.22 & 0.60 & 18.6 & 0.61 & 0.00 & 0.11 \\
$\mathrm{C}$ & 48.5 & 0.28 & 0.16 & 30.5 & 1.15 & 0.26 & 18.3 & 0.76 & 0.01 & 0.10 \\
$\mathrm{D}$ & 46.9 & 0.35 & 0.22 & 31.1 & 1.28 & 0.46 & 19.0 & 0.59 & 0.01 & 0.13 \\
E & 47.6 & 0.77 & 0.65 & 29.8 & 1.41 & 0.26 & 19.1 & 0.36 & 0.00 & 0.07 \\
\hline
\end{tabular}

As shown in Table 12, the pyroxenes analyzed all varied between 0.58-1.57 En, 56.6158.23 Fs, and 41.08-42.72 Wo. Groups B and D were slightly more enriched in $\mathrm{MgO}$ with higher En end member values.

Table 13. Average clinopyroxene ternary component by group

\begin{tabular}{lccc}
\hline Group & En & Fs & Wo \\
\hline $\mathrm{A}$ & 0.58 & 57.91 & 41.51 \\
$\pm \sigma$ & 0.48 & 0.36 & 0.33 \\
$\mathrm{~B}$ & 1.57 & 57.05 & 41.39 \\
$\pm \sigma$ & 1.14 & 1.01 & 0.21 \\
$\mathrm{C}$ & 0.69 & 58.23 & 41.08 \\
$\pm \sigma$ & 0.56 & 0.4 & 0.31 \\
$\mathrm{D}$ & 1.18 & 57.5 & 41.4 \\
$\pm \sigma$ & 0.83 & 1.11 & 0.75 \\
$\mathrm{E}$ & 0.67 & 56.6 & 42.7 \\
$\pm \sigma$ & 1.49 & 1.48 & 0.5 \\
\hline
\end{tabular}




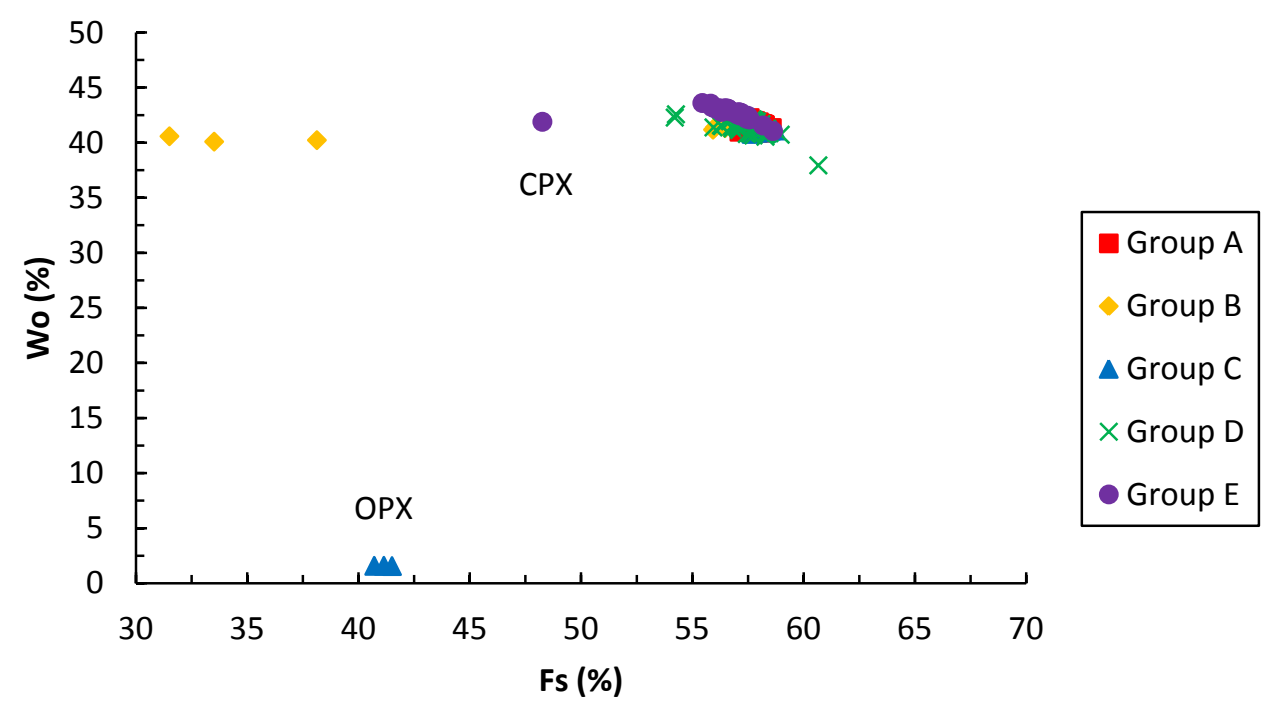

Figure 14. Fs vs. Wo pyroxene end member components by group. The clinopyroxenes cluster together, with group $B$ and group $C$ having outlying orthopyroxene crystals which were not commonly observed within the samples analyzed and represent a small subset of crystals present.

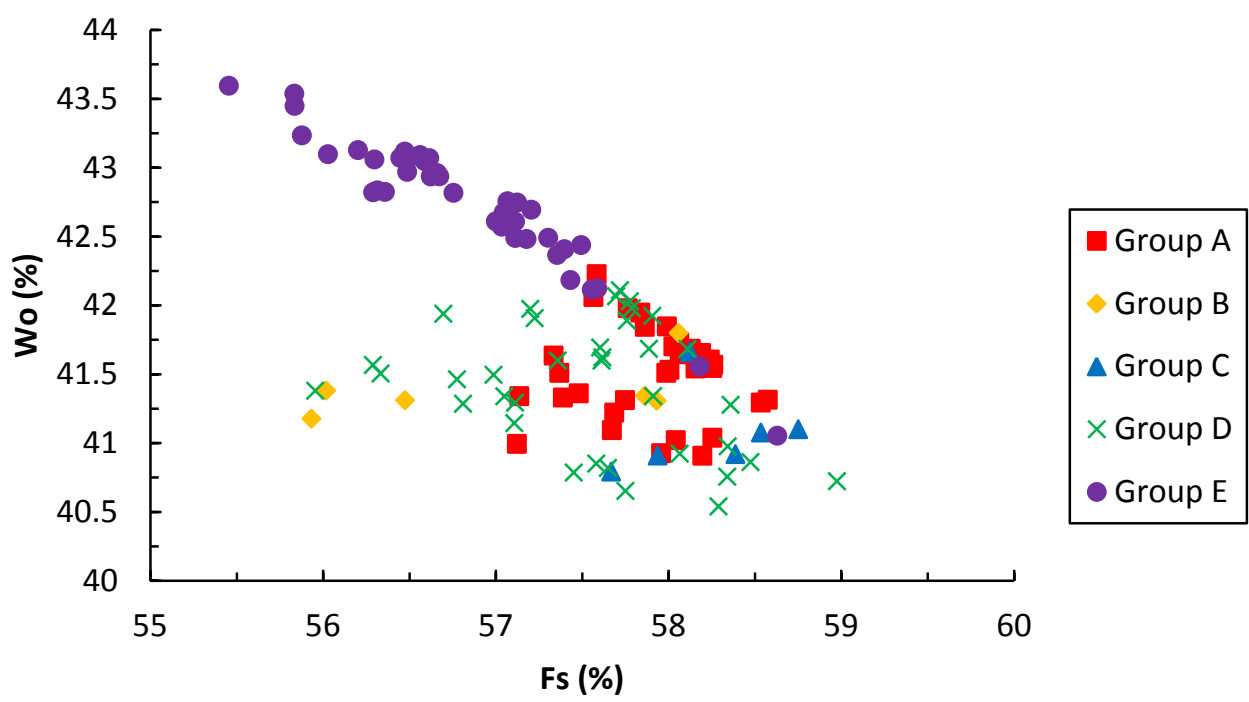

Figure 15. Fs vs. Wo pyroxene end member components by group zoomed in on clustered data from Figure 14. Two features are noted when the clustered data is enlarged, first, the rhyolite groups display no apparent trend but appear as a cloud with large overlaps between rhyolite groups $A$ through $\mathrm{D}$, secondly, the dacite sample does display a clear negative slope with increasing FeO that has some overlap with the rhyolite groups but largely lay outside of the cloud of rhyolite pyroxene samples. 
Clinopyroxenes found in both the dacite and rhyolite pumices all exist within a tight compositional spread when examining major oxides (Figures 14 and 15), with all clinopyroxenes having a composition between $\sim 55-59$ Fs $\%$ and $\sim 40-44$ Wo $\%$, however, several outlier clino- and orthopyroxene crystals were observed that generally reflect slightly decreasing En \%, but exist independent of any particular group, occurring in groups B, C, and E and may be xenocrysts that did not crystallize from the observed magmas.

\section{Trace elements}

The clinopyroxenes analyzed using LA ICP-MS displayed a wide range in trace element concentrations both within group and between groups as shown in Table 14. There is a large overlap between the rhyolite groups A through D while the dacite group E remains compositionally distinct with the lowest concentrations in REE elements and the highest concentration in elements such as $\mathrm{Ti}$ and Mn. Group A, the air fall pumice unit, is particularly enriched in $\mathrm{Zn}, \mathrm{Zr}$, Ce, and LREEs relative to all other groups. Considerable overlap is displayed between pyroxenes, however, both group E and A are distinct as shown in Figures 16-18. When examining incompatible trace elements in Figure 19, group E mirrors the pattern displayed by most rhyolite groups while being more depleted. Group B displays a different pattern relative to all other groups, particularly in HREEs such as $\mathrm{Nb}$ and $\mathrm{Ta}$ where it is more enriched relative to both dacite and rhyolite groups. 
Table 14. Average LA ICP-MS clinopyroxene trace elements by group.

\begin{tabular}{|c|c|c|c|c|c|c|c|c|c|c|}
\hline Conc. (ppm) & A & $\pm \sigma$ & $\mathrm{B}$ & $\pm \sigma$ & $\mathrm{C}$ & $\pm \sigma$ & $\mathrm{D}$ & $\pm \sigma$ & E & $\pm \sigma$ \\
\hline \# of analyses & 8 & & 5 & & 5 & & 13 & & 7 & \\
\hline $\mathrm{Sc}$ & 13.41 & 1.45 & 61.71 & 81.44 & 20.33 & 4.98 & 15.95 & 3.24 & 27.06 & 7.13 \\
\hline $\mathrm{Ti}$ & 1096.81 & 169.95 & 3224.24 & 4142.45 & 1477.62 & 287.50 & 1273.79 & 221.11 & 3580.91 & 460.74 \\
\hline V & 4.24 & 3.29 & 36.17 & 48.45 & 17.69 & 10.72 & 10.56 & 7.79 & 1.45 & 0.83 \\
\hline $\mathrm{Mn}$ & 9242.27 & 504.70 & 9604.98 & 1046.42 & 10236.47 & 751.64 & 9973.61 & 830.50 & 11938.10 & 227.64 \\
\hline $\mathrm{Zn}$ & 1024.77 & 109.49 & 800.31 & 120.53 & 820.55 & 73.25 & 873.82 & 120.90 & 461.32 & 64.97 \\
\hline $\mathrm{Rb}$ & 0.13 & 0.06 & 0.52 & 0.85 & & & 0.10 & 0.03 & 0.07 & 0.03 \\
\hline $\mathrm{Sr}$ & 0.71 & 0.36 & 5.94 & 5.35 & 2.58 & 1.47 & 1.63 & 1.12 & 1.82 & 0.63 \\
\hline Y & 453.22 & 19.89 & 326.49 & 159.07 & 391.36 & 73.42 & 353.57 & 74.74 & 142.23 & 29.44 \\
\hline $\mathrm{Zr}$ & 302.57 & 57.62 & 211.70 & 163.89 & 254.97 & 101.90 & 225.47 & 68.92 & 121.43 & 12.74 \\
\hline $\mathrm{Nb}$ & 0.22 & 0.07 & 2.92 & 5.96 & 0.24 & 0.03 & 0.24 & 0.10 & 0.55 & 0.23 \\
\hline $\mathrm{Ba}$ & 1.48 & 0.33 & 3.56 & 4.47 & 1.60 & 0.28 & 1.66 & 0.51 & 0.79 & 0.23 \\
\hline $\mathrm{La}$ & 105.88 & 30.27 & 105.86 & 42.03 & 143.62 & 31.98 & 122.47 & 23.00 & 61.34 & 17.58 \\
\hline $\mathrm{Ce}$ & 388.87 & 79.96 & 362.94 & 148.50 & 468.90 & 64.91 & 434.55 & 59.13 & 196.25 & 50.96 \\
\hline $\operatorname{Pr}$ & 75.11 & 13.88 & 67.24 & 29.42 & 86.34 & 9.08 & 78.18 & 7.21 & 34.87 & 8.71 \\
\hline $\mathrm{Nd}$ & 394.37 & 71.03 & 339.40 & 156.68 & 449.76 & 38.91 & 400.42 & 32.18 & 181.27 & 43.76 \\
\hline $\mathrm{Sm}$ & 113.62 & 9.51 & 87.35 & 45.82 & 110.17 & 12.47 & 98.75 & 11.72 & 39.97 & 8.86 \\
\hline $\mathrm{Eu}$ & 2.46 & 0.74 & 3.20 & 0.37 & 2.95 & 0.24 & 2.64 & 0.43 & 2.78 & 0.23 \\
\hline $\mathrm{Gd}$ & 115.00 & 8.71 & 87.23 & 47.61 & 107.48 & 18.28 & 95.88 & 15.84 & 36.75 & 7.65 \\
\hline Dy & 101.59 & 5.98 & 74.47 & 41.35 & 90.43 & 17.46 & 79.75 & 17.11 & 30.86 & 7.48 \\
\hline Er & 61.78 & 3.76 & 42.96 & 21.60 & 53.62 & 10.59 & 49.01 & 10.63 & 19.16 & 3.82 \\
\hline $\mathrm{Yb}$ & 84.88 & 6.76 & 53.20 & 32.37 & 68.86 & 18.60 & 64.06 & 16.64 & 25.36 & 5.62 \\
\hline $\mathrm{Hf}$ & 10.49 & 1.60 & 6.84 & 5.29 & 8.30 & 3.48 & 7.08 & 2.78 & 4.52 & 0.57 \\
\hline $\mathrm{Ta}$ & & & 0.34 & & & & & & 0.05 & \\
\hline $\mathrm{Pb}$ & 2.16 & 0.33 & 1.29 & 0.78 & 1.44 & 0.57 & 1.63 & 0.61 & 0.47 & 0.15 \\
\hline Th & & & 0.26 & 0.00 & 0.34 & & 0.15 & 0.03 & 0.09 & 0.04 \\
\hline $\mathrm{U}$ & & & 0.03 & & 0.06 & & 0.05 & & 0.06 & \\
\hline
\end{tabular}




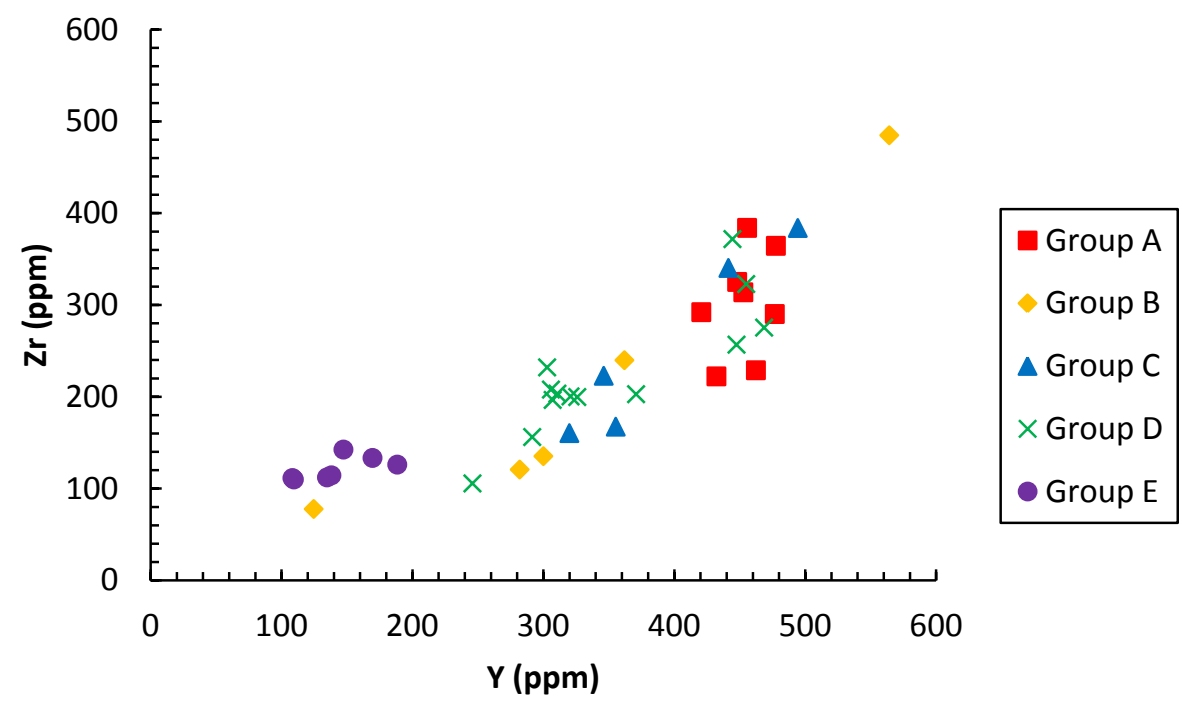

Figure 16. Y vs. Zr in ppm in clinopyroxenes using LA ICP-MS data. Group E forms a cluster with the lowest $\mathrm{Y}$ and $\mathrm{Zr}$ concentrations. Group $\mathrm{B}$ spans the entire concentration range of analyzed crystals, having the lowest and highest $\mathrm{Y}, \mathrm{Zr}$, concentrations. Groups B through D all overlap with a group A forming a loose cluster of data.

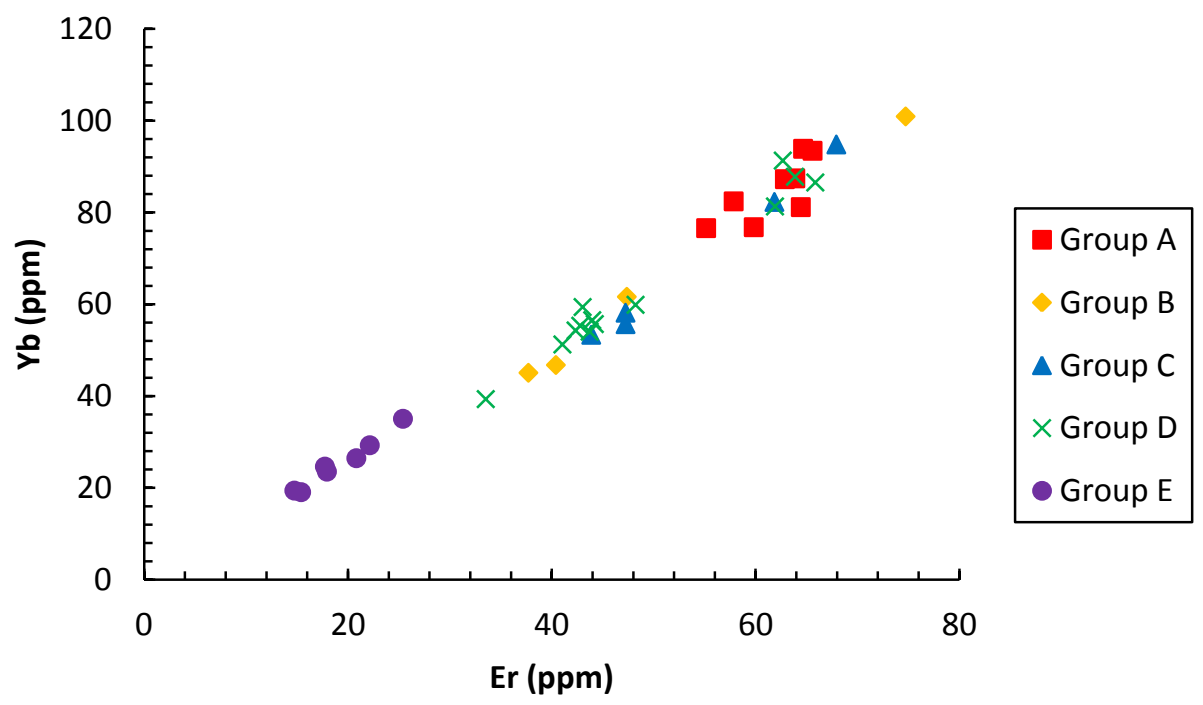

Figure 17. Er vs. Yb in ppm in clinopyroxenes using LA ICP-MS trace data. Group E forms a distinct grouping of data, representing the least enriched compositions in $\mathrm{Er}$ and $\mathrm{Yb}$. A second grouping of data consisting of groups B through $D$ forms an intermediate composition while a third grouping of data consisting of groups A through D representing the most enriched compositions. A single crystal from group B represents the most enriched composition in $\mathrm{Er}$ and $\mathrm{Yb}$. Note that crystals from group A represent the most enriched composition amongst all groups when comparing Er and $Y b$. 


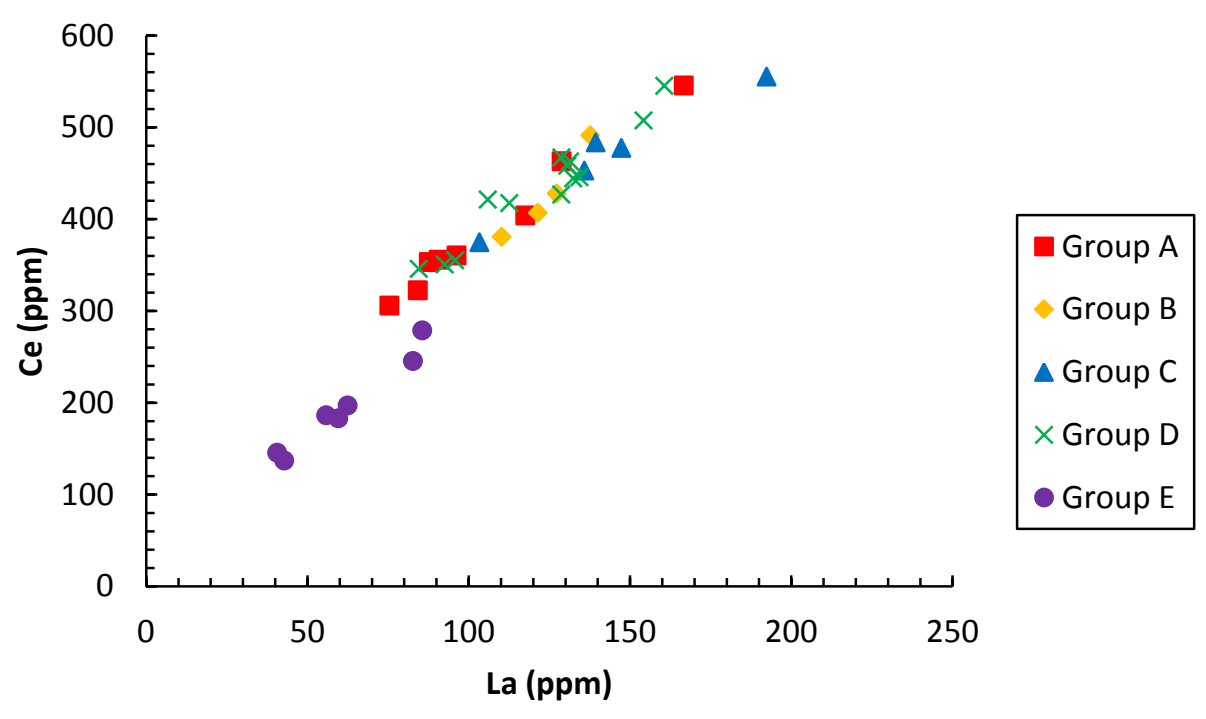

Figure 18. Ce vs. La in ppm in clinopyroxenes using LA ICP-MS trace element data. Group E forms the less enriched end of the overall positive linear trend, but does not exhibit the same degree of separation from the rhyolite groups when compared to Figure 17. In contrast with Figure 17, Group A represents the second least enriched composition, however, groups A through D all display a large amount of overlap with each other.

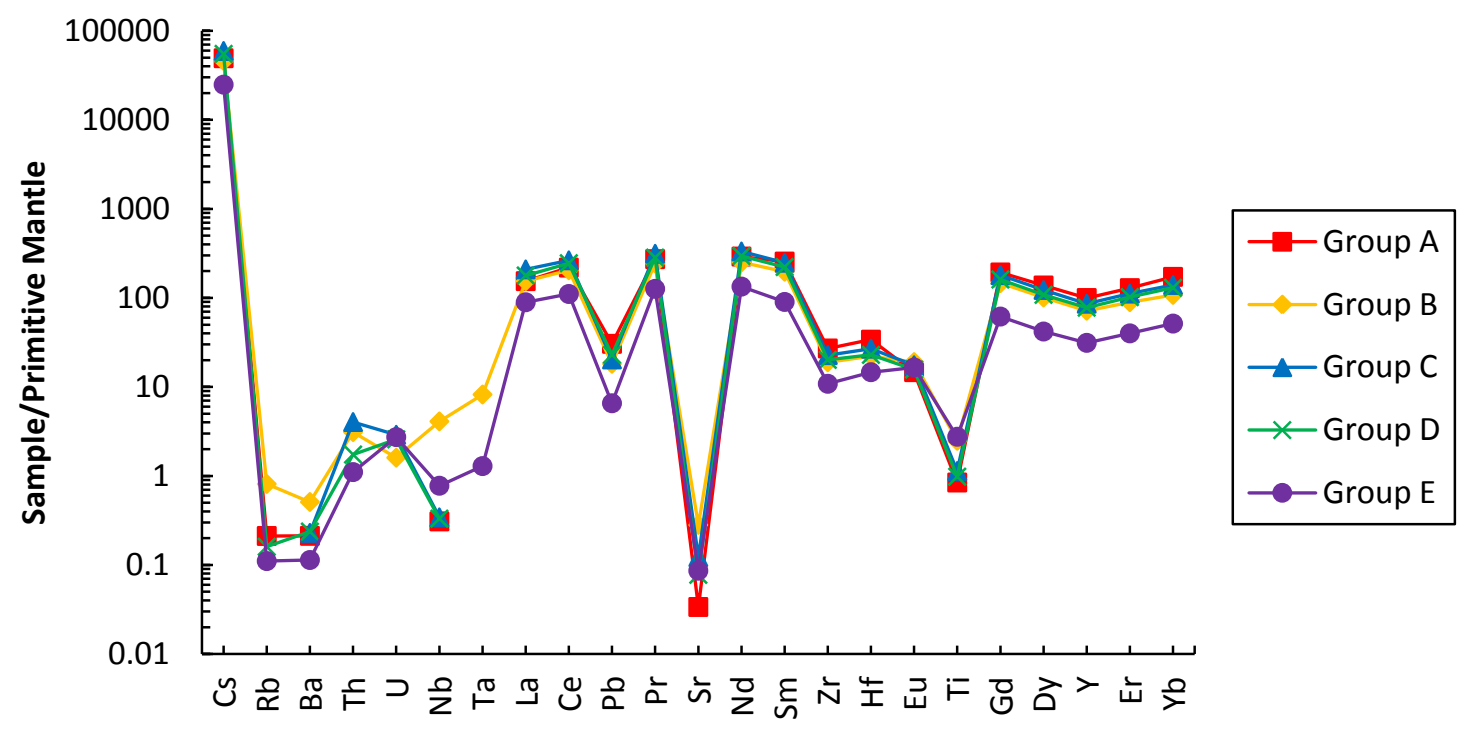

Figure 19. Spider diagram of average group pyroxene incompatible elements normalized to primitive mantle composition from Sun and McDonough (1989). All groups display troughs in $\mathrm{Rb}, \mathrm{Ba}, \mathrm{Pb}, \mathrm{Sr}$, and Ti. With the exception of Sr, group A represents the most enriched concentrations from La to Yb, however, from Rb to Ta, group B represents the most enriched concentrations in HREEs, displaying a pattern that deviates from the otherwise consistent shape of the spider diagram. Group $E$ is consistently the least enriched composition, particularly with regards to the HREEs, with the exception of Sr. 


\section{Olivines}

Several olivines were also analyzed with the mafic portion of crystals during EMP analysis (Table 15). Olivine (fayalite) exists as a minor phase within the DCT and is characteristic of the hot-dry-reduced rhyolites which the DCT belongs to, resulting from reducing conditions present in the magma where $\mathrm{Fe}^{2+}$ is more abundant than $\mathrm{Fe}^{3+}$ and is able to fit within the crystal lattice of fayalite olivine. This process is driven by the chemical reaction $2 \mathrm{Fe}_{3} \mathrm{O}_{4}+3 \mathrm{SiO}_{2}=3 \mathrm{Fe}_{2} \mathrm{SiO}_{4}+\mathrm{O}_{2}$ and the presence of quartz, fayalite, and magnetite help constrain the oxygen fugacity of a magma as a function of temperature. All olivines analyzed except for those in group A were fayalite $\left(\mathrm{Fe}_{2} \mathrm{SiO}_{4}\right)$, while group A, which consisted of a single olivine, displayed a much more MgO-rich composition closer to a forsterite $\left(\mathrm{Mg}_{2} \mathrm{SiO}_{4}\right)$. Group B through D olivines are all similar in composition, with group $\mathrm{E}$ having increased $\mathrm{TiO}_{2}$ and $\mathrm{CaO}$ with lower $\mathrm{MgO}$ when compared with olivines from groups B through D.

Table 15. Average weight percent EMP olivine composition by group.

\begin{tabular}{lcccccccccc}
\hline \hline Group & $\mathrm{SiO}_{2}$ & $\mathrm{TiO}_{2}$ & $\mathrm{Al}_{2} \mathrm{O}_{3}$ & $\mathrm{FeO}$ & $\mathrm{MnO}$ & $\mathrm{MgO}$ & $\mathrm{CaO}$ & $\mathrm{Na}_{2} \mathrm{O}$ & $\mathrm{Cr}_{2} \mathrm{O}_{3}$ & $\mathrm{ZnO}$ \\
\hline A & 34.3 & 0.16 & 0.03 & 40.6 & 0.77 & 23.69 & 0.3 & 0.00 & 0.00 & 0.07 \\
$\mathrm{~B}$ & 29.5 & 0.01 & 0.00 & 66.5 & 2.89 & 0.49 & 0.4 & 0.02 & 0.01 & 0.23 \\
$\mathrm{C}$ & 30.4 & 0.02 & 0.01 & 65.6 & 2.92 & 0.43 & 0.4 & 0.08 & 0.00 & 0.22 \\
$\mathrm{D}$ & 29.3 & 0.03 & 0.00 & 66.7 & 2.93 & 0.39 & 0.4 & 0.02 & 0.01 & 0.24 \\
E & 30.0 & 0.07 & 0.01 & 66.0 & 3.14 & 0.05 & 0.5 & 0.02 & 0.01 & 0.20 \\
\hline
\end{tabular}




\section{DISCUSSION}

The DCT displays a wide range of trace element concentrations despite having a narrow range of major element concentrations in both rhyolitic bulk tuff and bulk pumice samples analyzed. Mineral data generated in this study yields information on how these compositional gradients observed in rhyolitic magmas were generated, how they were stored within the magma reservoir, and what processes modified these magmas prior to eruption.

\section{Minerals Record Different Magma Compositions}

The minerals which crystallize from a melt serve as a record of magmatic composition and storage conditions, such as temperature, pressure, and volatile content, during crystallization and may preserve this chemical signature when removed from the melt they crystallized from. The rhyolites of the DCT exhibit little variation in major element concentrations but significant variation in trace element concentrations between groups in both bulk tuff and individual mineral samples (Greene, 1973; Wacaster et al., 2011). This wide range of trace element concentrations within a narrow range of major element concentrations serves as the basis for dividing the DCT magma which was evacuated in a single eruptive episode into separate rhyolite batches. Based on major and trace element data from feldspars and pyroxenes, the crystals of rhyolite groups A through D are shown to be distinct from the dacite group E. Furthermore, trace element data can be variable among crystals from different rhyolite magmas, despite that feldspars are nearly indistinguishable by major element compositions. Particularly the air fall pumice unit, group A, which despite having the most enriched bulk tuff composition 
in incompatible trace elements does not reflect the same enrichment when examining feldspars and pyroxenes from group A. When examining the feldspar populations, the dacite group has considerable spread in major elements in alkali feldspars with minor overlap with data from feldspars belonging to the rhyolite groups (Figures 8 and 9), however, when examining trace elements the dacite forms a distinct group with a compositional gap between group $\mathrm{E}$ feldspars and those belonging to the rhyolites (Figures 10 through 12). Trace element data of feldspars from the rhyolite groups shows strong overlap between groups A through D, however, groups B and C tend to form clusters of data when examining Figures 10 through 12, presenting rhyolite groups B and $\mathrm{C}$ as those containing feldspars with the highest incompatible trace element compositions (e.g. Rb). The pyroxenes display a comparable pattern with a similar separation between the rhyolite groups and the dacite group when examining trace elements compositions (Figures 15-17). Pyroxenes also display considerable overlap between rhyolite groups. The pyroxenes do not form clusters of data that separate the rhyolite groups themselves but rather form a cloud of data with all rhyolite groups overlapping without a clear pattern.

Group E clinopyroxenes are more enriched in Wo \% when comparing end member components relative to the rhyolite groups. The group E pyroxenes do not overlap extensively pyroxenes observed in the rhyolites groups but rather form a loose trend line which leads into the cluster of data formed by the rhyolite groups with a compositional gap separating the dacite pyroxenes from the rhyolite pyroxenes. The pyroxenes belonging to the rhyolite groups do not display any apparent pattern or trend, 
as shown in Figure 14. This overlap of trace element data in the clinopyroxenes found in the rhyolite groups do not reflect the same changing trace element patterns found in the feldspar crystals. This may suggest pyroxenes were formed earlier than alkali-feldspars from rhyolitic magma that may have not yet developed the observed compositional zonation. The feldspar minerals examined in the rhyolite groups formed distinct clusters of data while clinopyroxenes appear as a loose cluster which does not track with any major or trace elemental variation but reflects a single yet variable population of crystals which are dispersed relatively among the rhyolite groups with a higher concentration in group D, the least evolved rhyolite composition.

The shape, texture, and abundances of observed phenocrysts also serve to differentiate crystal populations and the magmatic conditions they were subject to. Feldspar and pyroxene crystals observed in the rhyolites were single euhedral to subhedral, such as quartz in form of dipyramid crystals. While single crystals exist in the dacite group, a majority (>>50\% visual estimation) of the crystals in group E were glomerocrysts or crystal aggregates of alkali feldspar, clinopyroxene, and quartz contrasting with only single crystals of these mineral phases in rhyolites. Due to the glomerocrystic texture of group E, it was not viable to manually sort the crystals to determine mineral phase proportionalities by size fraction. All crystals observed in both dacite and rhyolite pumices displayed embayment of the crystal faces which may correspond to a drop in pressure preceding the eruption which deposited the DCT (Greene, 1973). 
Group A, the air fall pumice unit, is the most enriched in incompatible trace elements when comparing bulk tuff and bulk pumice samples, however, when comparing trace element data of feldspar and pyroxene crystals from all rhyolite groups, group A is not the most enriched in incompatible elements. Instead, groups B and C contain crystals that record the most enriched compositions for all rhyolite groups. Group A also has the lowest overall crystallinity, with little evidence for zonation in either the feldspars or pyroxenes core-rim pairs, suggesting that while the liquid component of the magma that constituted group A was more evolved relative to the other rhyolite groups while the crystals suspended in the melt were compositionally similar to those from groups $\mathrm{C}$ and D.

Based on these observations, two populations of crystals are present in the DCT, one population belonging to the rhyolite groups and another belonging to the compositionally variable but distinct dacite group. Hence, mineral data suggest at least two batches of magma were present prior to the eruption and emplacement of the ignimbrite.

\section{Magma Mixing to Produce Array of Rhyolites}

Magma mixing is an important process for generating compositional diversity in magmas by mixing magmas of varying compositions and/or melted crustal rock (Ruprecht et al., 2012; Laumonier et al., 2014). Convective stirring, magma mingling, and chamber overturn are commonly cited magma mixing processes. The efficiency of two magmas to mix is controlled by the composition, crystallinity, temperature, and 
volatile content which in turn affect magma viscosity and density (Carrasco-Nunez et al., 2012; Ruprecht et al., 2012; Laumonier et al., 2014).

While volcanic complexes represent complicated open systems, the mixing of two end member components is a useful simplification for observing potential relationships between magmas of different compositions. Examination of the collected physical data, bulk tuff and pumice chemical data, as well as single crystal chemical data suggest that the range of observed rhyolites may have been produced through mixing of two end member rhyolitic magma compositions to produce the suite of rhyolites present. Using a binary mixing model shown in Equation 1, any relationship between two end member magma compositions would be represented by a straight line if they are related by mixing, an observation noted among the DCT bulk tuff trace elements shown in Figure 3 and Figure 4. To test this assumption, the following magma mixing equation was employed:

$$
M=A x+B(1-x),(\text { Equation } 1)
$$

where $\mathrm{M}$ is the concentration of the resulting mixture in weight percent (or ppm), $\mathrm{A}$ is the concentration of the most evolved rhyolite in weight percent, $\mathrm{x}$ is the proportion of $\mathrm{A}$ involved in mixing where $0 \leq \mathrm{x} \leq 1$, and $\mathrm{B}$ is the concentration of the least evolved rhyolite in weight percent (or ppm). To evaluate the role of magma mixing in producing the array of rhyolites observed, group A was selected as the most evolved composition and group D was selected as the least evolved composition, and groups B and C, rhyolitic magmas that plot between both end member compositions when comparing trace element 
concentrations, were used for $\mathrm{M}$ to evaluate the mixing parameter, $\mathrm{x}$, by rearranging Equation 1 to produce Equation 2:

$$
x=\frac{M-B}{A-B},(\text { Equation } 2)
$$

the results of which are displayed in Figures 20 and 21. Trace elements were evaluated using primarily ICP-MS bulk pumice data with supplementary XRF bulk pumice data where needed. The fit of the model was evaluated using the relative standard deviation (RSD):

$$
R S D=\left(\frac{\text { standard deviation }}{\text { mean }}\right) \times 100 .(\text { Equation } 3)
$$




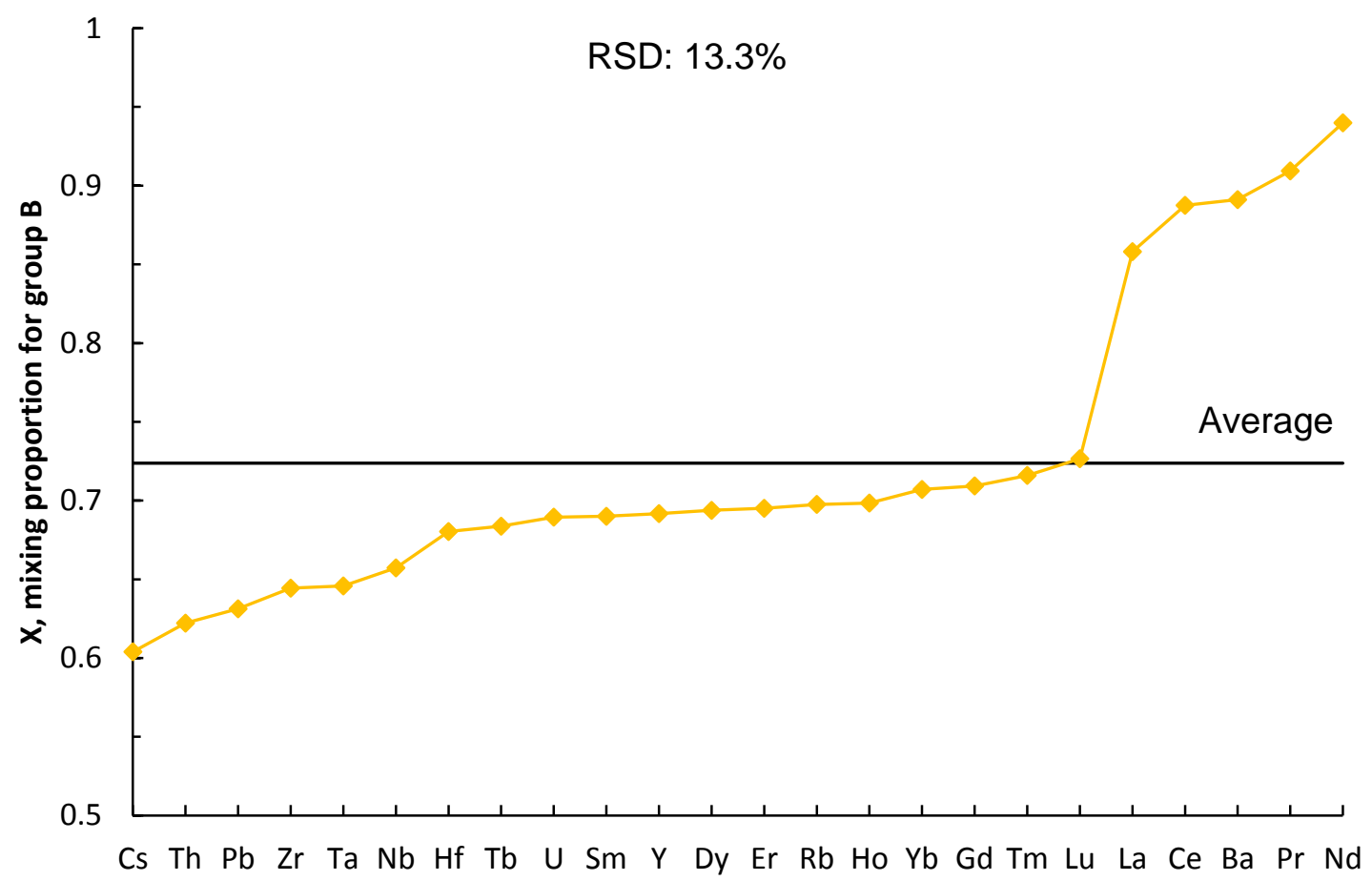

Figure 20. Mixing proportions, $X$, for group $B$ rhyolite. The average mixing proportion, $X$, is displayed as a horizontal black line. The magma mixing model provides a rough fit for LREEs and some HREEs, however, a linear relationship is not observed. The relative standard deviation for the model for group B is $\mathbf{1 3 . 3 \%}$. 


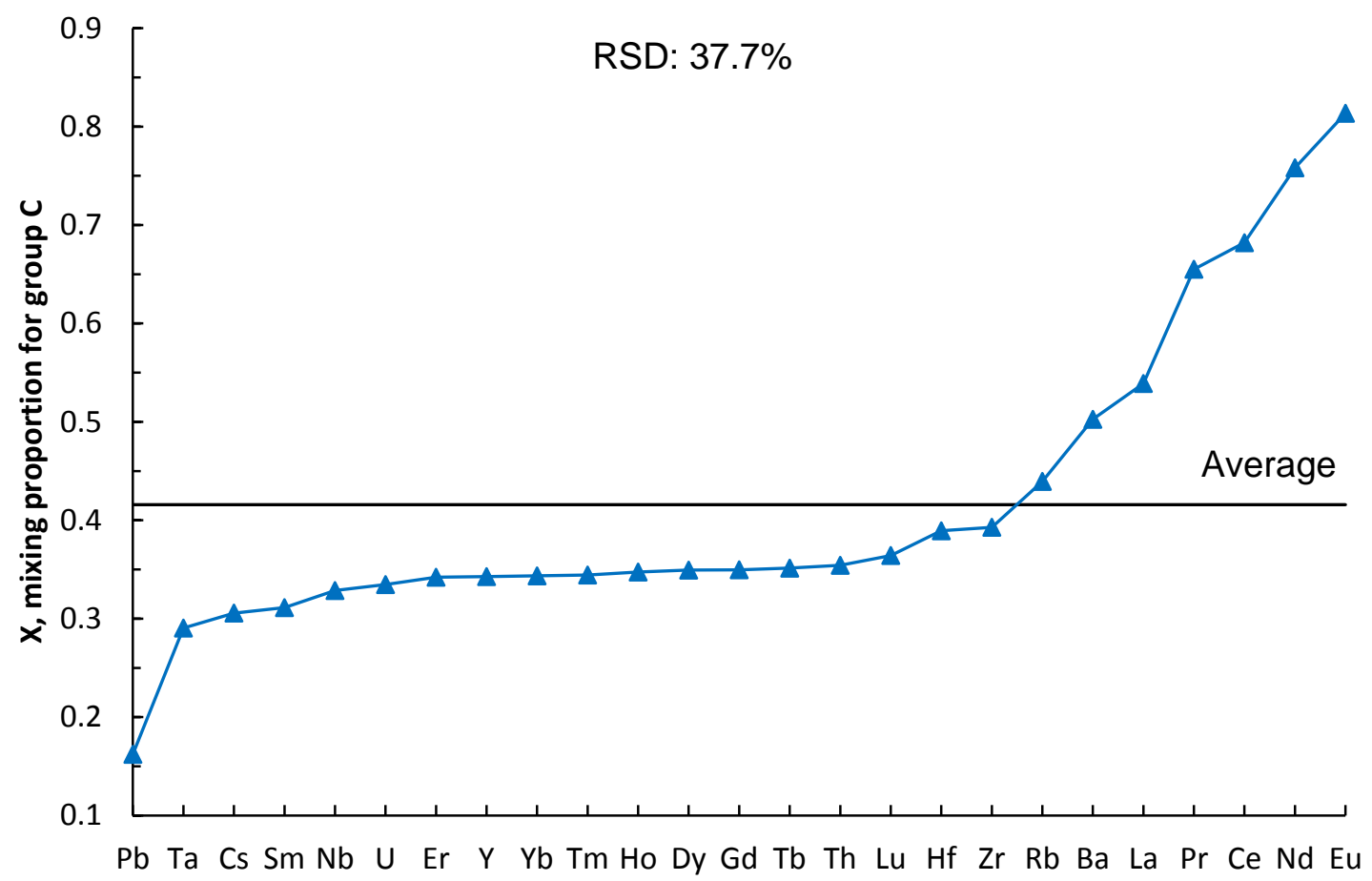

Figure 21. Mixing proportions, $X$, for group $C$ rhyolite. The average mixing proportion, $X$, is displayed as a horizontal black line. Similar to Figure 20, the magma mixing model provides a rough fit, however, a linear relationship is not observed. The relative standard deviation for the model for group $\mathrm{B}$ is $\mathbf{3 7 . 7 \%}$, signifying the fit for the magma mixing model is less accurate for group $\mathrm{C}$ being the mixing product of groups $\mathrm{A}$ and $\mathrm{D}$.

Magma mixing between rhyolites cannot adequately account for the observed trace element patterns using ICP-MS data. Ideally, the proportionality would be the same among all trace elements for groups B and C and closely parallel the average value displayed by the black line in Figures 20 and 21, however this pattern was not generated. While magma mixing does provide a rough fit, particularly for the heavy rare earth elements and some light rare earth elements, it was invalid for Eu, Sr, and Sc. This pattern may be altered by LREE incorporating accessory mineral phases, e.g. chevkinite. Overall, magma mixing may play a role in the diversity of rhyolitic magmas composing the DCT but was not the sole mechanism which produced the suite of rhyolites observed. 
Discussing these findings in more detail, since the magmas composing the rhyolite pumices are very close in bulk composition with no overt differences with respect to major element composition, the mixing parameters calculated for major elements yield inconsistent results and often indicate no mixing solution (i.e. returning a value $<0$ or $>1$ for $\mathrm{X})$. When comparing trace element mixing parameters between groups B and $\mathrm{C}$, ideal mixing between groups $\mathrm{A}$ and $\mathrm{D}$ would produce a consistent value for $\mathrm{X}$ for all trace elements for both groups B and C. However, calculated values for X for rhyolite B and C vary significantly for most trace elements. Similar to major elements, in the case where trace element concentrations of rhyolite end members are very close, the equation yields no solutions (e.g. Eu, Sr, and Sc). The variability of $\mathrm{X}$ for most trace elements may be viewed as refuting evidence that intermediate rhyolite compositions are generated by mixing of end members $\mathrm{A}$ and $\mathrm{D}$ rhyolites. If magma mixing did exert a significant control on producing the array of rhyolites the observed variations in $\mathrm{X}$ imply that the magmas have undergone considerable further modifications after mixing or that mixing processes were more complicated than the simple mixing of two end member compositions.

Physical evidence does exist for magma mixing with the DCT with the occurrence of banded or mingled pumices of rhyolitic and dacitic composition at the hand sample and outcrop scales (Wacaster et al., 2011). While magma mixing may partially account for the range of trace element concentrations observed within the array of rhyolites, the two end member rhyolite compositions of groups A and D were likely generated as the silicic melt residues from a crystallizing body of more intermediate magma. 


\section{Magma Storage Scenarios}

There are two magma reservoir models commonly invoked for the storage of chemically zoned magmas, (1) the traditional singular magma chamber that is zoned with respect to composition, temperature, crystallinity, and volatile content or (2) distinct magma reservoirs which house multiple magmas with varying degrees of separation from each other, either as discrete but interconnected pods of varying compositions or as multiple batches of magma separated by mushy crystal margins. This separation of silicic magmas allows for the evolution of discrete magmas with varying chemical compositions, mineral populations, and magmatic conditions despite potentially originating from the same underlying parent magma. These distinct magma compositions may then undergo varying degrees of mixing and withdrawal during eruptive events to produce the chemical and physical zonation apparent in the pyroclastic deposit emplaced during eruption. The storage configuration of the magmas and geometry of the magma reservoir has important implications for the production and evolution of discrete batches of silicic magmas (Hildreth, 2004; Carrasco-Nunez et al., 2012; Ellis et al., 2010; Ellis and Wolff, 2012; Ellis et al., 2014).

Using the similarities and differences of DCT bulk tuff, bulk pumice, and individual mineral samples as a measure for the proximity between rhyolitic and dacitic magma batches, the following observations can be made. There is considerable overlap between rhyolite groups A through D. Major element compositions of alkali feldspar and clinopyroxene are nearly indistinguishable among rhyolites. As discussed above, the spread is larger when considering trace element data, however, all rhyolites overlap or 
cluster. Minerals from the dacite magma are compositionally distinct with regards to major and trace elements and either slightly overlap with the rhyolite groups or are offset from the minerals compositions observed in the rhyolites by a compositional gap. This suggests that feldspar and pyroxene crystals composing the rhyolite groups are closely related to one another. Therefore it is implied that they crystallized from melt compositions under the same magma conditions, excluding the possibility of multiple, separate magma bodies as suggested by Ellis for SRP rhyolites (Ellis et al., 2010; Ellis and Wolff, 2012; Ellis et al., 2014). However, group E minerals clearly record magma conditions that are similar to yet different from those that produced the minerals observed in the rhyolites.

The dacite and rhyolite groups composing the DCT, however, display different crystallinities, with group A being 1-6\% (3.1\% average), groups B and C 1-18\% (7.0\% and $6.0 \%$ averages, respectively), group $\mathrm{D} \sim 14-45 \%$ (18.5\% average), and group $\mathrm{E} \sim 7-40$ (22.2\% average), with the low end values representing the smaller size fractions while the high end values typically representing the $<991-425 \mu \mathrm{m}$ size fraction. These contrasting crystallinities among rhyolites, while displaying the same feldspar and pyroxene major element compositions and similar trace elements compositions could be attributed to increasing volatile content towards the roof of the magma reservoir which decreases the solidus for minerals in the melt and therefore lowers the overall crystallinity. In summary, the similarities in mineral compositions suggest that these magmas were stored within a contiguous magma reservoir. The presence of several outlier ortho- and clinopyroxenes suggest these minerals may be xenocrysts or antecrysts which did not 
crystallize from any observed magma recorded. Therefore, not all magmas may be present in the pyroclastic material composing the DCT and these outlier minerals may originate from a progenitor magma or a magma which was not erupted.

\section{Crystal Mush Model}

The crystal mush model is frequently called upon for the generation of large volumes of crystal-poor rhyolite from an intermediate (dacitic) crystal mush in a variety of tectonic regimes, particularly continental arc and intra-plate hotspot settings. In the crystal mush model, a magma reservoir begins to cool by losing heat to the surrounding wall rock, assimilation of crustal rock, and mixing with cooler magmas. As heat is lost, thermal- and density-driven convection and chamber turnover, which serves to homogenize the thermal and chemical composition of the magma and keep crystals suspended within the magma body, slows and eventually stops as the crystallinity and therefore viscosity of the magma increases. As convective stirring decreases, crystals are able to be separated from the melt more efficiently. However, this process is very slow due to high viscosity of silicic magmas ( $\sim 10^{5} \mathrm{~Pa}$ s). When magmas are at $\sim 45-65 \%$ crystallinity, convection ceases as adjacent crystals begin to touch one another, forming a semi-rigid crystal framework or skeleton (Bachmann and Bergantz, 2004; Hildreth, 2004; Bachman and Bergantz, 2008; Wolff and Ramos, 2013; Ellis et al., 2014). Crystal-melt separation can only occur by compaction of the crystal mush once convection ceases, at which point the interstitial liquid in the void space between crystals has evolved towards a rhyolitic composition if the bulk magma composition of the crystal mush is dacitic. The expulsion of these interstitial melts from an intermediate crystal mush can produce a 
crystal-poor high-silica rhyolitic magma. This process may occur multiple times as the crystal fraction and temperature of the crystal mush may not be homogenous and subject to change over geologic time, such as when less evolved mafic magmas are injected into the base of the magma reservoir, providing additional thermal input and remelting the crystal mush or if the injection rate is high enough, disruption of the crystal framework and convective stirring. Also, interstitial rhyolitic melt may not be fully expelled from the crystal mush during compaction, allowing the remaining liquid to evolve before being potentially extracted later (Bachmann and Bergantz, 2004; Bachmann and Bergantz, 2008; Streck, 2014; Wolff and Ramos, 2014; Wolff et al., 2015). If DCT rhyolites are generated through melt extraction from a dacitic crystal mush, the first extraction of melt from the crystal mush would yield the rhyolite most enriched in incompatible trace elements, which would compose the group A rhyolite. During the second interstitial melt extraction, likely aided by partial melting of the crystal mush initiated by mafic magma injection to induce melting coupled with compaction to expel the rhyolitic melt would produce a rhyolite nearly identical in major element composition, yet less enriched in incompatible trace elements, forming the group D rhyolite. The subsequent mixing of these two rhyolitic magmas with nearly indistinguishable major elements but distinct trace element compositions could produce the array of rhyolite trace element compositions observed with modification by other magma evolution processes such as crystal fractionation and assimilation (Wolff et al., 2006; Wolff et al., 2012; Wolff and Ramos, 2013; Streck, 2014). If rhyolites A and D were related in the context of such a mush model, one early observation is the following. The composition of the group D 
rhyolite cannot be accounted for by mixing the group A rhyolite with a higher proportion of crystals derived from the intermediate crystal mush. If so, then group D could be modeled as group A plus the addition of $\sim 13 \%$ crystals (i.e. the difference in crystallinity between rhyolite groups A and D) from the crystal mush (either modeled by using group D crystals, or potentially represented by the glomerocrysts of dacite forming group E). In either case, mass balance calculations indicate that a $\sim 13 \%$ 'dilution' effect from the addition of crystals would produce a rhyolite with $\sim 1200 \mathrm{ppm} \mathrm{Zr}$ as opposed to the 547 Zr ppm observed in the group E dacite. Similar mismatches occur with other trace elements as well. This indicates that group D cannot be produced by adding minerals derived from the crystal mush to group A rhyolite. Instead, group D would need to be assembled in a different way, possibly from melting the incompatible element depleted crystal mush to arrive at a composition of group D. 
INITIAL CONDITION

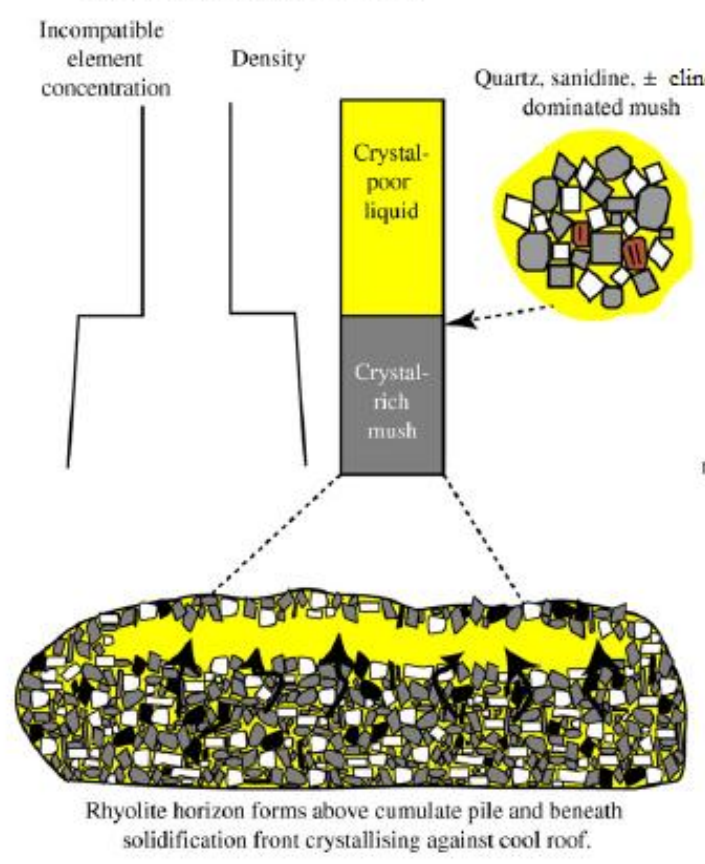

FOLLOWING RECHARGE

Incompatible

element Density

concentration
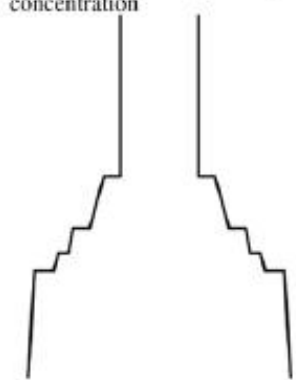

Figure 22. Schematic of cumulate remelting to produce compositionally zoned crystal-poor rhyolitic magma from an intermediate crystal mush. Remelting of the underlying crystal mush could produce the dacitic composition observed in the DCT, supported by the glomerocrystic texture of minerals in group E. Figure modified from Wolf et al. (2015).

Another question is how was the intermediate crystal-rich dacitic magma generated as recorded by the group E pumice. One potential method that could produce the crystal-rich dacite is the remelting of cumulates from the crystal mush (Figure 22). This process is driven by recharge of the magma reservoir, essentially hot, mafic magma is injected at the base of the magma reservoir, providing heat (up to $150{ }^{\circ} \mathrm{C}$ increase in temperature locally) and causing partial melting of the crystal mush. Depending on the injection rate of the mafic magma, the recharge event may also physically disrupt the crystal mush if the injection rate is sufficiently vigorous to distribute crystal aggregates throughout the magma reservoir. These displaced fragments of the crystal mush may be present in the form of glomerocrysts from the group E dacite. Magma recharge events 
may also serve as an important trigger in causing explosive eruptions. There are several observations which support this reasoning, first, group E exhibits embayment and rounding of the crystals, with chemical zonation of the feldspars, suggesting these crystals were removed from equilibrium conditions without sufficient time to reequilibrate. Also, the glomerocrystic texture of group E phenocrysts with intergrowth between mineral phases may represent fragments of the crystal mush from which the dacite was derived by dissolution and mixing of the crystal mush with the residual interstitial melt (Deering et al., 2011; Bachmann et al., 2014; Streck, 2014; Wolff et al., 2015). However, the distinct mineral compositions of the group E dacite argues against the minerals constituting the crystal mush at the time of melt extraction being incorporated into any of the rhyolites given that the minerals which crystallized from the rhyolites are compositionally different. 


\section{CONCLUSIONS}

Large-volume silicic eruptions often display gradients in chemical composition, crystallinity, temperate, and volatile content. By examining the pyroclastic deposits from caldera-forming eruptions the processes governing the generation and storage of compositionally zoned high-silica rhyolites can be examined. The DCT of eastern Oregon erupted $>300 \mathrm{~km}^{3}$ of pyroclastic material as a variably welded ignimbrite during a single eruptive episode which displays strong gradients in trace elements despite a relatively homogenous major element composition of bulk tuff and bulk pumice samples. This study presents new physical data comparing crystallinity and mass proportions of minerals in different rhyolitic and dacitic magma compositions observed in DCT pumices examined as well as EMP and LA ICP-MS chemical data for feldspar and pyroxene crystals.

The five pumice groups A through E serve as a frozen snapshot of erupted magmas from most to least evolved bulk compositions (e.g. most enriched in incompatible trace elements) were selected from across the observed range of trace element in bulk tuff and bulk pumice DCT samples. Four rhyolitic pumices and one dacitic pumice were selected to serve as a representative sample for each group to evaluate how mineral compositions, crystallinity, and mineral proportions change within and between each group. Crystallinity was found to vary systematically from the dacite group having the highest average crystallinity of $22 \%$ and the most evolved rhyolite group having the lowest average crystallinity of $3 \%$. Within each sample the crystal fraction peaks between 991 and 125 microns, with $<991-425 \mu \mathrm{m}$ being the volumetrically 
significant phenocryst-bearing size fraction in all pumice groups. Crystals were sorted into mafic and felsic phases for all rhyolitic pumices (groups A through D), with quartz and sanidine being the primary felsic phases and hedenbergite, Fe- and Ti-oxides, and fayalite being the primary mafic phases. Average mafic crystal proportions were generally $<5 \%$ for the dacite and $<1 \%$ for all rhyolite groups except for group A. Felsic mineral proportions were approximately equal between quartz and feldspar, with an overall greater abundance of quartz versus feldspar. The group E dacite pumice phenocrysts formed crystal aggregates (glomerocrystic texture) and possessed higher proportions of mafic minerals than the rhyolite groups. Also, group E was the only group with increasing crystallinity with decreasing size fraction while all rhyolite groups displayed peak crystallinities at $<991-425 \mu \mathrm{m}$, resulting in a distinctly different pattern when evaluating crystallinity versus size fraction.

Chemical data for feldspars displayed largely homogeneous major element compositions with distinct clusters of data when comparing trace elements, separating feldspars observed within the rhyolites from those of the dacite. The feldspars in the rhyolites also clustered based on which group they were from, with groups B and C having the most evolved feldspar compositions while group A, the air fall pumice unit which possessed the most evolved bulk composition, plotted with the groups $\mathrm{C}$ and $\mathrm{D}$ feldspars. Feldspars in the group E dacite pumice displayed a wider range of trace elements and exhibited zonation with increasing $\mathrm{K}_{2} \mathrm{O}$ from core to rim while the feldspars in the rhyolites displayed no zonation. Clinopyroxenes also displayed large overlaps in major element composition, however, when comparing trace elements the pyroxenes do 
not form clusters by group but rather all groups A through D pyroxenes form a nebulous cluster of data with large overlap and no apparent distinction between groups when examining trace element variation diagrams, though group E pyroxenes do form a distinct trend with a compositional gap in contrast to groups A through D.

Single crystal chemical data display two populations of crystals: the feldspars extracted from the rhyolite groups with largely homogenous major element composition without any zonation which form distinct clusters when comparing trace elements and a second population of zoned feldspars with a wide range of trace element compositions from the dacite group with a compositional gap separating the rhyolite feldspars from the dacite feldspars. Pyroxenes display less separation in trace element composition than feldspars, however, while groups A through D pyroxenes display relatively homogenous major element compositions with large trace element overlaps, they remain distinct when comparing trace elements with group E pyroxenes. In summary, the DCT has two distinct populations of minerals with one population belonging to the rhyolite groups and a separate but related population belonging to the dacite group.

The range of trace element compositions observed in the rhyolitic bulk tuff and single crystal samples from the DCT may be explained through two separate melt extractions from an intermediate (dacitic) crystal mush where the first magma batch representing group $\mathrm{A}$ is the most enriched in incompatible trace elements, while the second magma batch representing group D is considerably less enriched yet would have the same major element composition. This model hinges on making rhyolite D during the second extraction from a crystal mush that has undergone partial melting after rhyolite A 
was extracted, therefore being more depleted in incompatible trace elements relative to the first extracted magma batch. Using observed crystal compositions in the rhyolites and the dacite makes this scenario problematic. The array of bulk rhyolite trace element compositions is generally incompatible with being produced by mixing groups A and D rhyolites. For this scenario, all rhyolitic magmas would need to be stored within close proximity within the magma reservoir for mixing to occur and homogenous crystal compositions and abundances excludes the existence of multiple discrete magmas stored separately in individual nearby magma reservoirs. The origin of the dacite magma is unlikely explained through partial melting of the crystal mush. However, neither remelting of the crystal mush or magma mixing fully account for the chemical trends observed in the DCT and the magmas were likely generated and modified by multiple, complex processes. The investigation of vitric ground mass compositions of sampled pumices would provide fruitful further research into elucidating the processes which formed the compositionally zoned rhyolites of the DCT.

The DCT provides a complex petrologic system to explore the applicability of current rhyolite magma generation models. However, while the models applied to the DCT silicic magmas provide an overview of major processes controlling the compositions of the melt and crystals, they do not provide a comprehensive explanation of the compositional zonation and discrepancies observed. Further study is required to discern what additional processes modified the observed rhyolites and fully test the applicability of the dacite magma being generated through remelted cumulates from the crystal mush. 


\section{REFERENCES}

Bachmann, O. and Bergantz, G.W., 2004, On the origin of crystal-poor rhyolites: extracted from batholithic crystal mushes: Journal of Petrology, v. 45, no. 6, p.1565-1582.

Bachmann, O., and Bergantz, G., 2008, The Magma Reservoirs That Feed Supereruptions: Elements, v. 4, p 17-21.

Bachmann, O, Deering, C.D., Lipman, P.W., and Plummer, C., 2014, Building zoned ignimbrites by recycling silicic cumulates: insight from the $1,000 \mathrm{~km}^{3}$ Carpenter Ridge Tuff, CO: Contributions in Mineral Petrology, v. 167, 13 p.

Carrasco-Nunez, G., McCurry, M., Branney, M.J., Norry, M., and Willcox, C., 2014, Complex magma mixing, mingling, and withdrawal associated with an intraPlinian ignimbrite eruption at a large silicic caldera volcano: Los Humeros of central Mexico: Geological Society of America Bulletin, v. 124, no. 11-12, p. 1793-1809.

Cathey, H.E. and Nash, B.P., 2004, The Cougar Point Tuff: Implications for Thermochemical Zonation and Longevity of High-Temperature, Large-Volume Silicic Magmas of the Miocene Yellowstone Hotspot: Journal of Petrology, v. 45, no. 1 , p. 27-58.

Cathey, H.E., and Nash, B.P., 2009, Pyroxene thermometry of rhyolite lavas of the Bruneau-Jarbidge eruptive center, Central Snake River Plain: Journal of Volcanology and Geothermal Research, v. 188, p. 173-185.

Christiansen, E.H., 2005, Contrasting processes in silicic magma chambers evidence from very large volume ignimbrites: Geology, v. 142, no. 6, p. 669-681.

Deering, C.D., Bachmann, O., and Vogel, T.A., 2011, The Ammonia Tanks Tuff: Erupting a melt-rich rhyolite cap and its remobilized crystal cumulate: Earth and Planetary Science Letters, v. 310, p. 518-525.

Ellis, B.S., Barry, T., Branney, M.J., Wolff, J.A., Bindeman, I., Wilson, R., and Bonnichsen, B., 2010, Petrologic constraints on the development of a largevolume, high temperature, silicic magma system: The Twin Falls eruptive centre, central Snake River Plain: Lithos, v. 120, p. 475-489.

Ellis, B.S., Wolff, J.A., Boroughs, S., Mark, D.F., Starkel, W.A., and Bonnichsen, B., 2013, Rhyolitic volcanism of the central Snake River Plain: a review: Bulletin of Volcanology, v. 75, 19 p. 
Ellis, B.S., Bachmann, O., and Wolff, J.A., 2014, Cumulate fragments in silicic ignimbrites: The case of the Snake River Plain: Geology, v. 42, p. 431-434.

Ford, M.T., Grunder, A.L., and Duncan, R.A., 2013, Bimodal volcanism of the High Lava Plains and Northwestern Basin and Range of Oregon: Distribution and tectonic implications of age-progressive rhyolites: Geochemistry, Geophysics, Geosystems, v. 14, no. 8, p. 2836-2853.

Gelman, S.E., Deering, C.D., Bachmann, O., Huber, C., and Gutierrez, F.J., 2014, Indentifying the crystal graveyards remaining after large silicic eruptions: Earth and Planetary Science Letters, v. 403, p. 299-306.

Greene, R.C., 1973, Petrology of the Welded Tuff of Devine Canyon, Southeastern Oregon: U.S. Geological Survey Professional Paper 797, 36 p.

Hildreth, W., 1981, Gradients in Silicic Magma Chambers: Implications for Lithospheric Magmatism: Journal of Geophysical Research, v. 86, no. B11, p. 10153-10192.

Hildreth, W., 2004, Volcanological perspectives on Long Valley, Mammoth Mountain, and Mono Craters: several contiguous but discrete systems: Journal of Volcanology and Geothermal Research, v. 136, p. 169-198.

Jordan, B.T., Grunder, A.L., Duncan, R.A., and Deino, A.L., 2004, Geochronology of age-progressive volcanism of the Oregon High Lava Plains: Implications for the plume interpretation of Yellowstone: Journal of Geophysical Research, v. 109, 19 p.

Laumonier, M., Scaillet, B., Pichavant, M., Champallier, R., Andujar, J., and Arbaret, L., 2014, On the conditions of magma mixing and its bearing on andesite production in the crust: Nature Communications 5:5607.

Ross, C.S. and Smith, R.L., 1961, Ash-Flow Tuffs: Their Origin, Geologic Relations and Identification: Geological Society Professional Paper 366, 87 p.

Ruprecht, P., Bergantz, G.W., Cooper, K.M., and Hildreth, W., 2012, The Crustal Magma Storage System of Volcan Quizapu, Chile, and the Effects of Magma Mixing on Magma Diversity: Journal of Petrology, v. 53, no. 4, p 801-840.

Smith, R.L., 1960, Ash Flows: Geological Society of America Bulletin, v. 71, no. 6, 47 p.

Streck, M.J. and Grunder, A.L., 1997, Compositional Gradients and Gaps in High-silica Rhyolites of the Rattlesnake Tuff, Oregon: Journal of Petrology, v. 38, no. 1, p. 133-163. 
Streck and Grunder, 2008, Phenocryst-poor rhyolite of bimodal, tholeiitic provinces: the Rattlesnake Tuff and implications for mush extraction models: Bulletin of Volcanology, v. 70, p. 385-401.

Streck, M.J., 2014, Evaluation of crystal mush extraction models to explain crystal-poor rhyolites: Journal of Volcanology and Geothermal Research, v. 284, p. 79-94.

Wacaster, S., Streck, M.J., Belkin, H.E., and Bodnar, R.J., 2011, Compositional zoning of the Devine Canyon Tuff, Oregon: American Geophysical Union, Fall Meeting 2011, abstract \#V21C-2517.

Wolff, J.A., 1985, The effect of explosive eruption processes on geochemical patterns within pyroclastic deposits: Journal of Volcanology and Geothermal Research, v. 26, p. 189-201.

Wolff, J.A., Wark, D.A., Ramos, F.C., and Olin, P.H., 2006, Petrologic evidence for thermal rejuvenation of crystal mush in the Bandelier Tuff: American Geophysical Union, Fall Meeting 2006, abstract \#V24C-01

Wolff, J.A., Ramos, F.C., and Olin, P.H., 2012, Compositional zoning in high-silica rhyolite tuffs: American Geophysical Union, Fall Meeting 2012, abstract \#V43D2888.

Wolff, J.A., and Ramos, F.C., 2014, Processes in Caldera-Forming High-Silica Rhyolite Magma: $\mathrm{Rb}-\mathrm{Sr}$ and $\mathrm{Pb}$ Isotope Systematics of the Otowi Member of the Bandelier Tuff, Valles Caldera, New Mexico, USA: Journal of Petrology, v. 55, no. 2, p 345-375.

Wolff, J.A., Ellis, B.S., Ramos, F.C., Starkel, W.A., Boroughs, S., Olin, P.H., and Bachmann, O., 2015, Remelting of cumulates as a process for producing chemical zoning in silicic tuffs: a comparison of cool, wet and hot, dry rhyolitic magma systems: Lithos, v. 236, p. 275-286. 